\title{
When risks need attention: adoption of green supply chain initiatives in the pharmaceutical industry
}

\section{Kumar, A}

http://hdl.handle.net/10026.1/12850

\subsection{0/00207543.2018.1543969}

International Journal of Production Research

Taylor \& Francis

All content in PEARL is protected by copyright law. Author manuscripts are made available in accordance with publisher policies. Please cite only the published version using the details provided on the item record or document. In the absence of an open licence (e.g. Creative Commons), permissions for further reuse of content should be sought from the publisher or author. 


\title{
When risks need attention: adoption of green supply chain initiatives in the pharmaceutical industry
}

\begin{abstract}
The pharmaceutical industry is very important in delivering life-saving products/services to society. There are many ways for materials/products/services concerned with pharmaceuticals to influence the environment; these include improper disposal of pills/tablets by patients, expired and unused medications, improper release of drugs by pharmacies or household sewage mixed with surplus drugs. In view of this, the present work seeks to integrate green supply chain (GSC) concepts in the pharmaceutical sector in a developing economy Indian context. In so doing, managers need to determine the potential risks in adopting GSC initiatives to achieve sustainability in operational perspectives. In this sense, this work seeks to distinguish the potential risks in adopting GSC initiatives within the pharmaceutical industry. This work uses a literature review and fuzzy Delphi approach in finalising the risks. This research also uses fuzzy Analytical Hierarchy Process (AHP) for prioritisation of the risks under vague and unclear surroundings. According to the findings, cold chain technology and supply risks categories are highly prioritised. This work can assist practising managers and government authorities in effectively developing and managing GSC initiatives in line with sustainable development goals in the context of the pharmaceutical industry. Finally, a sensitivity test is applied to evaluate the stability of ranking of risks.
\end{abstract}

Keywords: Risk; Green Supply Chain; Sustainable Production; Pharmaceutical industry; Fuzzy Delphi; Fuzzy AHP; India.

\section{Introduction}

In order to satisfy customer demands, a robust supply chain is essential for the flow of goods/information/money through producers and suppliers, transporters, warehouses, retailers and stakeholders (Chopra and Meindl, 2001; Bai and Sarkis, 2014). In the pharmaceutical industry, drugs are produced, transferred and consumed. Therefore it must be considered somewhat different from other physical goods supply chains due to its significance, storage, transportation and regulations (Narayana et al., 2014; Settanni et al., 2017; Moktadir et al., 2018). The primary goal of the pharmaceutical industry, while trying to be profitable, is to 
build the necessary supports for healthcare systems by providing essential medicines at the right time and to the right place (Settanni et al., 2017).

The pharmaceutical industry is growing rapidly in terms of enhancing research and design in the industry; however, proper execution of supply chain activities in this sector generates huge pharmaceutical waste, which is harmful to the environment and has a direct impact on human health (Xie and Breen, 2012; Faisal, 2016). In the last few decades, the consciousness of people about the environment has increased and regulatory bodies have also started to focus on world environmental issues such as scarcity of resources, global warming and carbon emissions (Xie and Breen, 2012; Tseng and Chiu, 2013). To help industries to minimise their ecological impact, managers and practitioners suggest employing green principles to its supply chain network (Xie and Breen, 2012). The pharmaceutical value chain accounts for sophisticated products and involves higher investment for research and development (Tseng and Chiu, 2013). The increased global and domestic pressures on environmental sustainability, economic and safety considerations (Jha, 2007; Breen and Xie, 2009) steer the pharmaceutical industry to manage green supply chain (GSC) initiatives in its business. GSC initiatives help to improve the pharmaceutical industry ecological and economic gains by recycling unused/unwanted medicines and disposing of products in an eco-friendly manner. From a holistic view, GSC initiatives in the pharmaceutical industry can be defined as the inclusion of green practices at each stage of the supply chain i.e. green sourcing, eco-friendly designing, green manufacturing, green distribution, reverse logistics etc (Narayana et al., 2014; Kumar et al., 2015; Mangla et al., 2013; Dubey et al., 2017).

Green sourcing (Jabbour et al., 2015) is recognised as an imperative aspect in the pharmaceutical sector, ensuring the procurement of material/products/services with minimal negative impact on the environment and society (Faisal, 2016; Dubey et al., 2017). Risk in GSC initiatives (Mangla et al., 2014) may create a threat to the stability of operations in the pharmaceutical industry. Therefore, risk to GSC may significantly affect pharmaceutical industry green sourcing decisions such as disruption in material supply, quality related concerns, increased environmental impacts, decreased competitive gains etc (Mangla et al., 2015b). As far as gaining a perspective to this work, to improvise performance and to manage GSC initiatives (considering a holistic picture of GSC), the concept of risks to GSC needs to be addressed (Mangla et al., 2015a).

The pharmaceutical Industry has grown exponentially in developing economies like India (Jha, 2007; Saranga and Phani, 2009). The Indian pharmaceutical industry has the potential to grow to USD 55 billion by 2020 (Bhadoria et al., 2012; Patil et al., 2016). Notably, about 
4,057 tons of waste is generated by healthcare facilities in India per day; this includes expired medications, contaminated products and drugs which are unused and/or obsolete (Patil et al., 2016; Thakur and Ramesh, 2018). There are many sources for pharmaceutical based materials/products/services to influence the environment such as improper disposal of pills/tablets by patients, expired and unused medications, expulsion of pesticides and molecular farming waste, improper release of drugs by pharmacies, household sewage mixed with surplus drugs, leaching from unmanaged landfills, veterinary medicines or chemical additives in animal food (Bhadoria et al., 2012; Patil et al., 2016).

In view of this, the present work seeks to integrate GSC concepts in the pharmaceutical sector in India. In doing so, managers need to determine the potential risks in adopting GSC initiatives to achieve sustainability in operational practice (Mangla et al., 2014). In addition, managers also need to establish the priority of pharmaceutical GSC based risks. Driven by this need, this work aims to answer two research questions; (i) What are the key risks to adopting GSC initiatives in the pharmaceutical industry in India? (ii) How are these risks to be evaluated to determine their priority in efficient integration of GSC initiatives in the pharmaceutical industry?

To answer these research questions, this work has several objectives. Firstly, is to distinguish the potential risks in adopting GSC initiatives in the pharmaceutical industry. This work uses a literature review and fuzzy Delphi approach verified through expert agreement (Luthra et al. 2018) in finalizing the risks. Secondly, we aim to propose a technique to reveal the priority of these risks in effectively managing the GSC initiatives. This research uses fuzzy Analytical Hierarchy Process (AHP) (Mangla et al., 2017) for prioritization of the risks under vague and unclear surroundings.

The present study is organized as follows. Relevant literature is provided in Section 2. The proposed solution methodology is given in Section 3. In Section 4, an arbitrary organisational example is illustrated along with the sensitivity analysis test. Discussions and implications for managers are provided in Section 5. Finally, conclusions that summarise contributions, limitations and future scope of work are illustrated in Section 6.

\section{Literature Review}

This section contains literature on risks to GSC initiatives in the pharmaceutical industry, provides problem definitions and research contributions made by this study. 


\subsection{Risks to GSC initiatives in pharmaceutical industry}

It is extremely difficult to predict future policy, due to the involvement of risks in operations (Wiengarten et al., 2016). Risk could be expressed as a tendency for something to happen that disrupts normal operations/activities (Mangla et al., 2015b). Consider for example, the failure of a new product or project. Risk could also be regarded as variance from an expected mean that may influence operations and processes in a supply chain context (Mishra et al., 2012; Jiménez-González and Overcash 2014). In line with this, based on Mangla et al. (2015a), risks in the context of GSC are defined as........ "occurrence of unforeseen events that might affect the green material movement and even disrupt the proposed flow of eco-friendly materials and finished green products from their point of origin to the point of consumption in business."

Pharmaceutical products are specifically linked to community (Saranga and Phani, 2009; Narayana et al., 2014). Thus, the supply chain plays a crucial role in distributing medicines/materials to stakeholders in the pharmaceutical industry (Moktadir et al., 2018); adding GSC initiatives may transform the industry to become environmentally friendly and more responsible to the community (Patil et al., 2016). GSC concepts in the pharmaceutical sector involve optimum utilization of resources as opposed to traditional supply chain practices. However, the presence of risks could waste resources as well as influence decisions of accepting GSC ideas (Mangla et al., 2016). Some negative effects of GSC risks include quality issues, supply failures and disruptions in the workflow, thereby disturbing ecological balance and causing a decline in business sales (Zavadskas et al., 2010; Qianlei, 2012; Samvedi et al. 2013). The consequence could be catastrophic if managers are not able to identify and manage these risks in a timely manner (Yang and Li, 2010; Ma et al., 2012). In this context, this work lists forty two potential risks to GSC initiatives in the pharmaceutical industry through a literature review. The listed risks were confirmed in the Indian scenario through expert feedback (please refer to Section 4.1 for more details). A brief description of literature supported risks is given in Table 1. 
Table 1. List of risks to GSC initiatives in the pharmaceutical industry

\begin{tabular}{|c|c|c|}
\hline Risks & Brief description & Sources \\
\hline 1.Design risk & $\begin{array}{l}\text { Any flaw in designing the process of GSC related to the } \\
\text { product or service. }\end{array}$ & $\begin{array}{l}\text { Tang and Musa (2011); Qianlei (2012); Wang et } \\
\text { al. (2012); Rostamzadeh et al. (2018) }\end{array}$ \\
\hline 2. Scarcity of skilled labour & $\begin{array}{l}\text { Lack of awareness and understanding of the concepts of } \\
\text { GSC and its operations from labour viewpoints. }\end{array}$ & $\begin{array}{l}\text { Olson and Wu (2011); Mangla et al. (2015a); } \\
\text { Govindan et al (2017) }\end{array}$ \\
\hline 3. Green technology level & $\begin{array}{l}\text { Risk involved in finding state of the art technology for } \\
\text { implementing the GSC process. }\end{array}$ & $\begin{array}{l}\text { Lintukangas et al. (2016);Rostamzadeh et al. } \\
\text { (2018) }\end{array}$ \\
\hline 4. Cost effective development & Risks related to adoption in more expensive green practices. & Wang et al. (2012); Rostamzadeh et al. (2018) \\
\hline 5. Machine or facility failure & $\begin{array}{l}\text { Risk related to machine or facility failure for implementing } \\
\text { the GSC process. }\end{array}$ & $\begin{array}{l}\text { Tang and Musa (2011); Olson and Wu (2011); } \\
\text { Govindan et al. (2017) }\end{array}$ \\
\hline 6. Procurement cost risk & $\begin{array}{l}\text { Risks related to disturbances in procurement of green or eco- } \\
\text { friendly raw materials. }\end{array}$ & $\begin{array}{l}\text { Olson and Wu (2011); Mangla et al. (2015b); } \\
\text { Lintukangas et al. (2016) }\end{array}$ \\
\hline 7. Supplier quality issues & $\begin{array}{l}\text { Raw materials and services supplied will affect the quality of } \\
\text { the green products. }\end{array}$ & $\begin{array}{l}\text { Tang and Musa (2011); Mangla et al. (2015a); } \\
\text { Rostamzadeh et al. (2018) }\end{array}$ \\
\hline 8. Green raw material disruptions & $\begin{array}{l}\text { Disturbances in supplying of any key green raw material } \\
\text { may disrupt the entire value chain. }\end{array}$ & $\begin{array}{l}\text { Mangla et al. (2015a); Sreedevi and Saranga } \\
\text { (2017); Rostamzadeh et al. (2018) }\end{array}$ \\
\hline $\begin{array}{l}\text { 9. Lack of collaborative } \\
\text { relationships }\end{array}$ & $\begin{array}{l}\text { Risks related to issues in mutual understandings among } \\
\text { stakeholders. }\end{array}$ & $\begin{array}{l}\text { Lintukangas et al. (2016); Brusset and Teller } \\
\text { (2017); Kumar et al. (2018) }\end{array}$ \\
\hline 10. Supplier failures & Risk related to failure of any key supplier in a GSC context. & Lintukangas et al. (2016); Kumar et al. (2018) \\
\hline $\begin{array}{l}\text { 11. Issues in availability of raw } \\
\text { material }\end{array}$ & $\begin{array}{l}\text { Inadequacy in availability of green raw materials may } \\
\text { disrupt the whole GSC }\end{array}$ & $\begin{array}{l}\text { Wang et al. (2012); Govindan et al (2017); } \\
\text { Rostamzadeh et al. (2018) }\end{array}$ \\
\hline 12. Reverse logistics design risk & Any flaw in designing the reverse logistics process & $\begin{array}{l}\text { Mangla et al. (2015a); Lintukangas et al. } \\
\text { (2016); Weraikat et al. (2016) }\end{array}$ \\
\hline 13. Gate-keeping policy issues & $\begin{array}{l}\text { Any flaw in design of the reprocessing station in terms of } \\
\text { screening and inspection of returned products. }\end{array}$ & $\begin{array}{l}\text { Mishra et al. (2012); Mangla et al. (2015b); } \\
\text { Rostamzadeh et al. (2018) }\end{array}$ \\
\hline $\begin{array}{l}\text { 14. Uncertainty in recovery of } \\
\text { pharmaceutical products }\end{array}$ & $\begin{array}{l}\text { Drugs recovered may be tampered with, and thus become } \\
\text { unsuitable for consumption }\end{array}$ & Narayana et al. (2014); Govindan et al (2017) \\
\hline $\begin{array}{l}\text { 15. Capacity and inventory related } \\
\text { disruptions }\end{array}$ & $\begin{array}{l}\text { Risks associated with capacity and inventory related } \\
\text { problems in recovering pharmaceutical products. }\end{array}$ & $\begin{array}{l}\text { Mangla et al. (2015a); Rostamzadeh et al. } \\
\text { (2018); Lücker et al. (2018) }\end{array}$ \\
\hline 16. Sourcing of funds & Risks related to disruptions in sourcing of funds. & $\begin{array}{l}\text { Olson and Wu (2011); Mangla et al. (2014); } \\
\text { Rostamzadeh et al. (2018) }\end{array}$ \\
\hline
\end{tabular}




\begin{tabular}{|c|c|c|}
\hline 17. Inventory costing issues & $\begin{array}{l}\text { This implies that high expenditure is needed as higher } \\
\text { inventory is required in the healthcare sector. }\end{array}$ & $\begin{array}{l}\text { Olson and Wu (2011); Bhattacharya et al. } \\
\text { (2014); Seker and Zavadskas (2017) }\end{array}$ \\
\hline 18. Financial budget constraints & $\begin{array}{l}\text { This risk is related to constraints in financial budgets as } \\
\text { research and trials of pharmaceutical products are highly } \\
\text { expensive. }\end{array}$ & $\begin{array}{l}\text { Olson and Wu (2011); Mangla et al. (2015a); } \\
\text { Rostamzadeh et al. (2018) }\end{array}$ \\
\hline 19. Shortage of lifesaving drugs & $\begin{array}{l}\text { This risk represents the shortage in supply of life saving } \\
\text { drugs required in emergencies. }\end{array}$ & Finch (2004); Mishra et al. (2012) \\
\hline 20. Market dynamics & Market supply and demand affects the GSC efficiency. & Mishra et al. (2012);Rostamzadeh et al. (2018) \\
\hline 21. Competing risk & $\begin{array}{l}\text { This risk represents the state of art in competition strategy } \\
\text { and approach of industries in GSC adoption in the health } \\
\text { sector. }\end{array}$ & $\begin{array}{l}\text { Olson and Wu (2011); Brusset and Teller } \\
\text { (2017); Rostamzadeh et al. (2018) }\end{array}$ \\
\hline 22. Product life cycle risks & $\begin{array}{l}\text { Pharmaceutical products are highly sensitive in terms of their } \\
\text { life cycle and impacts (from introduction to withdrawal). }\end{array}$ & $\begin{array}{l}\text { Olson and Wu (2011); Mishra et al. (2012); } \\
\text { Rostamzadeh et al. (2018) }\end{array}$ \\
\hline 23. Management policy failures & $\begin{array}{l}\text { Failure in management policies may disrupt the adoption of } \\
\text { GSC concepts in pharmaceutical industry effectively }\end{array}$ & $\begin{array}{l}\text { Olson and Wu (2011); Brusset and Teller } \\
\text { (2017); Rostamzadeh et al. (2018) }\end{array}$ \\
\hline 24. Failures of government polices & $\begin{array}{l}\text { Failure in government policies in terms of its design and } \\
\text { implementation would have a negative impact on GSC } \\
\text { adoption in pharmaceutical industry }\end{array}$ & $\begin{array}{l}\text { Mangla et al. (2015a); Brusset and Teller } \\
\text { (2017); Rostamzadeh et al. (2018) }\end{array}$ \\
\hline 25. Legal risk & $\begin{array}{l}\text { Risks include breaches of contract, rights to audit and } \\
\text { jurisdictions }\end{array}$ & $\begin{array}{l}\text { Mishra et al. (2012); Seker and Zavadskas } \\
\text { (2017); Rostamzadeh et al. (2018) }\end{array}$ \\
\hline $\begin{array}{l}\text { 26. Lack in enterprise strategic } \\
\text { goals }\end{array}$ & $\begin{array}{l}\text { Improper strategy planning and less priority given by higher } \\
\text { management in adopting GSC concepts in pharmaceutical } \\
\text { industry }\end{array}$ & $\begin{array}{l}\text { Finch (2004); Mangla et al, (2015b); Brusset } \\
\text { and Teller (2017); Rostamzadeh et al. (2018) }\end{array}$ \\
\hline 27. Legacy systems & $\begin{array}{l}\text { Old and outdated systems with inter-organizational } \\
\text { connectivity in adopting GSC concepts in pharmaceutical } \\
\text { industry }\end{array}$ & $\begin{array}{l}\text { Finch (2004); Xie and Breen (2012); Mangla et } \\
\text { al, (2015a); Rostamzadeh et al. (2018) }\end{array}$ \\
\hline $\begin{array}{l}\text { 28. Inconsistency in competitive } \\
\text { and supply chain strategies }\end{array}$ & $\begin{array}{l}\text { Risks related to mismatch between competitive and supply } \\
\text { chain priorities in adopting GSC concepts in pharmaceutical } \\
\text { industry. }\end{array}$ & $\begin{array}{l}\text { Faisal et al. (2006); Xie and Breen (2012); } \\
\text { Rostamzadeh et al. (2018) }\end{array}$ \\
\hline 29. IT infrastructure risks & $\begin{array}{l}\text { Risks related to IT infrastructure such as entire collection of } \\
\text { networks, data centres, software, hardware and related } \\
\text { equipment. }\end{array}$ & $\begin{array}{l}\text { Lintukangas et al. (2016); Modgil and } \\
\text { Sharma(2017); Rostamzadeh et al. (2018) }\end{array}$ \\
\hline 30. Inefficient IT applications & Any inadequacy in IT applications in adopting GSC concepts & Mangla et al, (2016); Lintukangas et al. (2016); \\
\hline
\end{tabular}




\begin{tabular}{|c|c|c|}
\hline & in pharmaceutical industry & Modgil and Sharma (2017) \\
\hline $\begin{array}{l}\text { 31. Inefficient use of materials and } \\
\text { energy }\end{array}$ & $\begin{array}{l}\text { Inefficient use of material and energy may create severe } \\
\text { ecological and social problems in healthcare sector. }\end{array}$ & Olson and $\mathrm{Wu}$ (2011); Wee and Aris (2017) \\
\hline $\begin{array}{l}\text { 32. Disturbances due to climate } \\
\text { change }\end{array}$ & $\begin{array}{l}\text { This represents the environmental impacts of global } \\
\text { warming and climate changes related to problems in } \\
\text { healthcare sector }\end{array}$ & $\begin{array}{l}\text { Samvedi et al. (2013); Finch (2004); Wee and } \\
\text { Aris (2017) }\end{array}$ \\
\hline $\begin{array}{l}\text { 33. Inadequacy in waste } \\
\text { management system }\end{array}$ & $\begin{array}{l}\text { Risk related to inefficiency in handling the waste in } \\
\text { pharmaceutical industry. }\end{array}$ & $\begin{array}{l}\text { Olson and Wu (2011); Samvedi et al. (2013); } \\
\text { Wee and Aris (2017) }\end{array}$ \\
\hline 34. Natural calamities & $\begin{array}{l}\text { This represents the occurrence and impact of natural } \\
\text { calamities on various activities associated with } \\
\text { pharmaceutical industry. }\end{array}$ & Mishra et al. (2012); Govindan et al. (2017) \\
\hline $\begin{array}{l}\text { 35. Inefficient anti-microbial } \\
\text { resistance }\end{array}$ & $\begin{array}{l}\text { The ability of micro-organisms such as bacteria, viruses or } \\
\text { fungi to develop resistance to drugs. }\end{array}$ & Ferri et al. (2017); Moktadir et al. (2018) \\
\hline $\begin{array}{l}\text { 36. Inefficient logistics network } \\
\text { design and support }\end{array}$ & $\begin{array}{l}\text { This represents inefficiency in logistics activities in the } \\
\text { transportation of green materials in pharmaceutical industry. }\end{array}$ & $\begin{array}{l}\text { Luthra et al. (2011); Mangla et al. (2015b); } \\
\text { Weraikat et al. (2016) }\end{array}$ \\
\hline 37. Uneven capacity district & $\begin{array}{l}\text { Every district involved in the pharmaceutical supply network } \\
\text { may have different capacity for storage of drugs }\end{array}$ & Mangla et al. (2015a); Mandal and Jha (2018) \\
\hline 38. Infrastructure failures & $\begin{array}{l}\text { This represents failure in infrastructure such as facility, } \\
\text { machines or high-tech equipment in adopting GSC concepts } \\
\text { in pharmaceutical industry. }\end{array}$ & $\begin{array}{l}\text { Finch (2004); Luthra et al. (2011); Xie and } \\
\text { Breen (2012) }\end{array}$ \\
\hline $\begin{array}{l}\text { 39. Irresponsible use of land and } \\
\text { facilities }\end{array}$ & $\begin{array}{l}\text { This represents a case of irresponsible use of materials, land } \\
\text { and facilities in adopting GSC concepts in pharmaceutical } \\
\text { industry. }\end{array}$ & $\begin{array}{l}\text { Mishra et al. (2012); Jiménez-González and } \\
\text { Overcash (2014) }\end{array}$ \\
\hline 40. Insurance risk & Risk related to high insurance/risk coverage premiums. & $\begin{array}{l}\text { Mishra et al. (2012); Mangla et al. (2016); } \\
\text { Mandal and Jha (2018) }\end{array}$ \\
\hline $\begin{array}{l}\text { 41. Inefficient process planning } \\
\text { and scheduling }\end{array}$ & $\begin{array}{l}\text { Risk occurred due to inefficient process planning and } \\
\text { scheduling in adopting GSC concepts in pharmaceutical } \\
\text { industry. }\end{array}$ & Luthra et al. (2011); Mishra et al. (2012) \\
\hline $\begin{array}{l}\text { 42. Inefficient } \\
\text { inventory levels }\end{array}$ & $\begin{array}{l}\text { Risk occurred due to insufficient/inefficient inventory levels } \\
\text { in adopting GSC concepts in pharmaceutical industry. }\end{array}$ & $\begin{array}{l}\text { Qianlei (2012); Kelle et al. (2012); Mangla et } \\
\text { al, (2015a) }\end{array}$ \\
\hline
\end{tabular}




\subsection{Problem definitions and research highlights}

The Indian pharmaceutical industry is unique in many ways (Jha, 2007; Kale and Little, 2007; Chittoor et al., 2008; Narayana et al., 2014); firstly, branded generic products account for 70-80 percent of the retail market in India. Secondly, local players have established themselves owing to early investments and their formulation development capabilities (Chittoor et al., 2008). Thirdly, fierce competition drives down the price levels in India (Jha, 2007). Currently, India ranks tenth in value and third in volume in the pharmaceutical sector of the global market. In order to provide better customer service and quality, it is important to manage the pharmaceutical supply network effectively (Jane Bower and Sulej, 2007; Patil et al., 2016). The Indian pharmaceutical industry contributes $10 \%$ of global production. The national contribution of the Indian pharmaceutical industry is 3.1-3.6 percent globally, responsible for approximately USD16.8 billion in 2016-17 in exports; growth of 30 percent is estimated by 2020. At this projected scale, the Indian market will be among the top pharmaceutical markets alongside US, China and Japan. According to the Indian Central Pollution Control Board, the majority of Indian drug factories dump their residues in an unsafe manner. Downstream wastewater from the Indian pharmaceutical industry was found to contain 150 times the level of toxic compounds as compared to the US; this may have a huge impact on the environment (Patil et al., 2016; Thakur and Ramesh, 2018). In this sense, greening the pharmaceutical supply network can help in increasing revenue and improving its commitment toward the environment and society. GSC means optimal utilization of resources with minimal wastage, thus producing maximum output and ecological efficiency (Mangla et al., 2015a; Dubey et al., 2017). Pharmaceutical industry practising managers have also realized that GSC initiatives not only show commitment towards the environment but also affect the overall performance while enhancing their market reputation among stakeholders (Qianlei, 2012). The integration of GSC may also include several risks (Yang and Li, 2010; Mangla et al. 2014) in the industry context. These risks needs to be identified and analysed extensively to ensure smooth functioning and effective utilisation of resources in pharmaceutical industry operations (Ruimin et al., 2012; Olson and Wu, 2011; Mangla et al., 2016). Additionally, the research on risk evaluation in integrating GSC initiatives is somewhat immature in the pharmaceutical sector compared to manufacturing, textile, automobile etc (Olson and Wu, 2011; Mangla et al., 2015b; Seker and Zavadskas, 2017). Therefore, this study is conducted to fill this research gap in the GSC agenda in the pharmaceutical sector. The prime contributions made by this research are listed as follow: 
- Listing the important risks in adoption of GSC initiatives in the Indian pharmaceutical industry using extensive literature review and expert inputs using fuzzy Delphi. This will give a proper understanding to managers about potential risks under vague surroundings.

- The finalised risks were analysed using fuzzy AHP for their priority. This priority order will help industry managers to understand their relative significance in managing GSC initiatives in the pharmaceutical industry.

- The managerial implications are provided based on the research outcomes to help managers and government bodies to achieve sustainable development goals in the pharmaceutical industry.

\section{Solution Methodology}

This work employs a two-phased research framework as presented in Fig.1. The first phase involves qualitative analysis i.e. previous studies evaluation and fuzzy Delphi method for identifying and finalising risks. The fuzzy AHP is utilised (in the second phase) to prioritise risks followed by managerial implications and contributions made in existing literature.

This work combines the fuzzy Delphi and fuzzy AHP methods due to the following reasons: (Ertuğrul and Karakaşoğlu, 2009; Tahriri et al., 2014; Kumar et al., 2017)

(i) The mixed fuzzy Delphi - AHP approach assists managers and practitioners in listing the potential risks in GSC initiatives in the pharmaceutical industry context in a most systematic way.

(ii) The mixed fuzzy Delphi - AHP assists managers in highlighting the most important risks in analysing the GSC initiatives in the pharmaceutical industry context.

The mixed fuzzy Delphi and fuzzy AHP research techniques are summarised in the following sub-sections. 


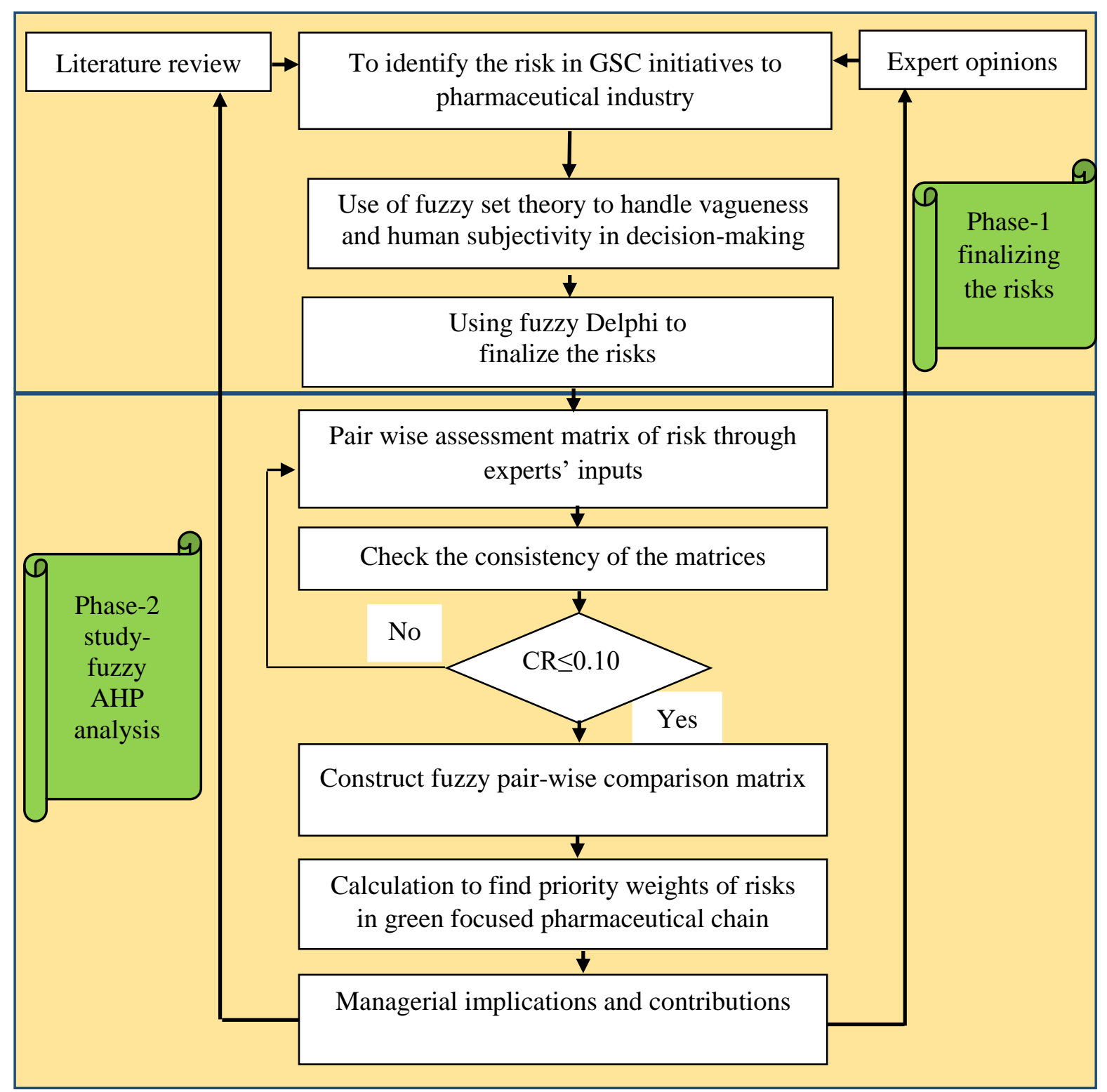

Fig.1 Research framework

\subsection{Fuzzy set theory}

Zadeh (1965) developed fuzzy set theory to capture human (qualitative) judgements in a decision-making problem. In an organisational supply chain context, decision-making is a complex process due to:

- Lack of clarity in data and information

- Human subjectivity in judgments

- Provision of linguistic judgments made by humans. 
Fuzzy set theory allows managers to elucidate human responses in crisp form for making decisions under vague and unclear surroundings (Zimmerman, 1996). Fuzzy set represents each number through binary numbers, 0 and 1 , which are specified in an interval $[0,1]$. According to Dubois and Prade, (1979), the fuzzy set based analysis can be illustrated as -if ' $\mathrm{X}$ ' elucidates a set of elements and the general component of ' $X$ ' is elucidated through ' $\mathrm{X}$ ' having values $\left(\mathrm{x}_{1}, \mathrm{x}_{2}, \mathrm{x}_{3} \ldots \ldots \ldots \mathrm{x}_{\mathrm{n}}\right)$. In this case, the fuzzy set $\mathrm{C}$ for $\mathrm{X}$ is expressed as $\left\{\left(\mathrm{x}, \mu_{C}(\mathrm{x})\right) \mid \mathrm{x} \in \mathrm{X}\right\}$. The membership of this fuzzy set $\mathrm{C}$ is defined through $\mu_{C}(\mathrm{x})$.

In this study, the triangular fuzzy number (TFN) - most suited to pragmatic situations (Mangla et al. 2015b) is used. Let us assume, ' $A$ ' and ' $B$ ' are two TFNs and represented as $A=\left(p_{1}, q_{1}, r_{1}\right)$ and $B=\left(p_{2}, q_{2}, r_{2}\right)$. The membership function for the TFN $(p, q, r)$ is calculated using the expression provided in Eq. (1).

$\mu_{c}(x)=\left\{\begin{array}{ll}0, & x \leq p \\ \frac{x-p}{q-p}, & x \in[p, q] \\ \frac{x-r}{q-r}, & x \in[q, r] \\ 0, & \text { otherwise }\end{array}\right\}(1)$

Then, the algebraic operations for $A$ and $B$ as per the extension principle,

1. $\mathrm{A} \oplus \mathrm{B}:\left(p_{1}, q_{1}, r_{1}\right) \oplus\left(p_{2}, q_{2}, r_{2}\right)=\left(p_{1}+p_{2}, q_{1}+q_{2}, r_{1}+r_{2}\right)$

2. A $\ominus \mathrm{B}:\left(p_{1}, q_{1}, r_{1}\right) \ominus\left(p_{2}, q_{2}, r_{2}\right)=\left(p_{1}-p_{2}, q_{1}-q_{2}, r_{1}-r_{2}\right)$

3. $\mathrm{A} \otimes \mathrm{B}:\left(p_{1}, q_{1}, r_{1}\right) \otimes\left(p_{2}, q_{2}, r_{2}\right) \cong\left(p_{1} p_{2}, q_{1} q_{2}, r_{1} r_{2}\right)$

4. $\Lambda(\mathrm{A} \otimes \mathrm{B}): \Lambda \otimes\left(p_{1}, q_{1}, r_{1}\right)=\left(\Lambda p_{1}, \Lambda q_{1}, \Lambda r_{1}\right)$

5. $\mathrm{A} \oslash \mathrm{B}:\left(p_{1}, q_{1}, r_{1}\right) \oslash\left(p_{2}, q_{2}, r_{2}\right) \cong\left(p_{1} / r_{2}, q_{1} / q_{2}, r_{1} / p_{2}\right)$

\subsection{Fuzzy Delphi method}

The Delphi method is a qualitative forecasting method for collecting views and information related to a specific area (Hsu et al., 2010). This method is most suitable to implement when there is no clear-cut resolution of a given policy issue while exploring an issue with a distributed group of people (Bouzon et al., 2016). The focus remains on the idea rather than the individuals; the overall record of accomplishment remains mixed. Ishikawa introduced fuzzy based Delphi in 1993. Fuzzy Delphi has the capability to capture vagueness in data and is widely used in different fields e.g. measurement of competence/performance (Kuo and Chen, 2008); technology selection (Hsu et al., 2010); supplier selection (Tahriri et al., 2014); 
logistics (Bouzon et al., 2016); GSC performance (Bhattacharya et al., 2014). Therefore, fuzzy Delphi to accommodate collective decision-making, with an aim to evaluate the risks in GSC initiatives in the Indian pharmaceutical industry is employed. A brief step-wise process of the fuzzy Delphi method (Ishizaka et al.,1993) is given below:

Step 1: This step deals with the extraction part, identification of the different risks related to the study. In this case, the different literature based risks to GSC adoption in the pharmaceutical industry were enlisted in a tabular form.

Step 2: After the identification of the risks, the document was circulated among the experts. Experts using a linguistic scale in the questionnaire evaluate the risk. Assume fuzzy number $\tilde{z}_{i j}$ to be the $j^{\text {th }}$ risk evaluation of the $i^{\text {th }}$ expert of $n$ experts (Bouzonet al., 2016).

$\tilde{z}_{i j}=\left(a_{i j}, b_{i j,}, c_{i j}\right)$ for $i=1,2,3, \ldots, n$ and $j=1,2,3, \ldots, m$.

Then the fuzzy weights of risks $\tilde{a}_{j}$ are given as follows: $\tilde{a}_{j}=\left(a_{j}, b_{j}, c_{j}\right)$, where

$a_{j}=\min \left(a_{i j}\right)$,

$b_{j}=\left(\prod_{i=1}^{n}\left(b_{i j}\right)\right)^{1 / n}$

$c_{j}=\max \left(c_{i j}\right)$, where $i=1,2, \ldots, n, j=1,2, \ldots m$

Step 3: In the last step, the mean method is used to determine $S_{j}$ by using Eq. (4).

$$
S_{j}=\left(a_{j}+b_{j}+c_{j}\right) / 3, \quad j=1,2, \ldots \ldots m
$$

For final selection of the risk, a threshold ( $\alpha$ ) is set if (1) If $S_{j} \geq \alpha$ accept the risk; (2) If $S_{j}<\alpha$ omit the risk.

\subsection{Fuzzy AHP}

The AHP method is useful in calculating the weight of concerned criteria and sub-criteria of a system (Saaty, 1980; Dağdeviren and Yüksel, 2008; Kumar and Dash, 2014; Ghorabaee et al., 2017). The AHP method reveals superior results compared to other knowledge based decision methods like ANP, TOPSIS and ELECTRE (Harputlugil et al., 2011). AHP is relatively easy to apply and simple to understand (Mangla et al., 2015a). In so doing, AHP has its own limitations such as rank reversal issues, human subjectivity problems and variable independence criteria (Mangla et al., 2016). In addition, AHP also fails to deal with the ambiguity in human judgment in decision-making problems (Chang, 1996; Abdullah and Najib, 2016; Mangla et al., 2015). To help decision makers, an AHP method can be revised to 
a Bayesian based modified AHP, Fuzzy AHP (Van Laarhoven and Pedrycz, 1983; Govindan et al., 2017; Mangla et al., 2017). Fuzzy AHP has been widely applied in several decision problems such as line balancing (Avikal, et al., 2014); supplier selection (Tahriri et al., 2014); performance evaluation (Ertuğrul and Karakaşoğlu, 2009); services evaluation (Lan et al., 2016); sustainability (Abdullah and Najib, 2016); sustainable production and consumption (Mangla et al., 2017).

Fuzzy AHP employs the following steps:

Step 1: Design the scale for data collection: experts are contacted to develop the pair wise comparison matrix for the risks as per designed questionnaire (see in Appendix A) on Saaty’s1-9 scale (Ertuğrul and Karakaşoğlu, 2009).

Step 2: Develop the fuzzy pair-wise assessment matrix: the fuzzy pair wise assessment matrix for risks is developed by integrating all experts' grades (Chen et al., 2016; Ertuğrul and Karakaşoğlu, 2009). In so doing, scholars may aggregate experts' judgements using different methods such as average method (Mangla et al., 2015a), geometric mean method (Moktadir et al., 2018), interval or range consideration technique (Nazam et al., 2015; Awasthi et al., 2018). In this work, we prefer to use an interval consideration method that evaluates the range of ratings provided by each expert. As a result, this method provides more consistent and reliable results compared to simple average and geometric average methods (Chen et al., 2006; Ertuğrul and Karakaşoğlu, 2008). The ratings of experts are provided using TFNs (a,b,c), where $i$ and $j$, represent number of rows and columns, and $k$ represents total number of experts. The expressions used for evaluating the range of ratings of experts are provided as below (see Eq. 5).

$$
\begin{aligned}
& \left(\tilde{x}_{i j}\right)=\left(a_{i j}, b_{i j}, c_{i j}\right) \\
& a_{i j}=\min _{k}\left(a_{i j k}\right), \\
& b_{i j}=\frac{1}{K} * \sum_{k=1}^{K}\left(a_{i j k}\right) \\
& c_{i j}=\max _{k}\left(a_{i j k}\right), \\
& \quad \text { where } i=1,2, \ldots, n, j=1,2, \ldots m \text {, and } k=1,2, \ldots, \text { K numberof experts }
\end{aligned}
$$

Step 3: Compute the priority weights: the priority weights of risks are calculated by converting fuzzy numbers into crisp values. In doing so, Chang's Extent Analysis method is 
used. This method has a wide applicability for establishing the relative priority weights of elements in any system (Chang, 1996).

$\mathrm{X}=\left\{x_{1}, x_{2}, \ldots, x_{n}\right\}$ is an object set and $\mathrm{G}=\left\{g_{1}, g_{2}, \ldots, g_{n}\right\}$ is a goal set. Based on Chang's extent method, the extent of an object with respect to each goal should be computed. This 'satisfactory extent' needs to be quantified through fuzzy numbers. Therefore, in this work, a fuzzy extent value (synthetic extent) is computed for each goal $\left(g_{i}\right)$ using triangle fuzzy number (TFN). While $m$ represents the number of extent analysis values for each object, it is expressed as:

$$
M_{g_{i}}^{1}, M_{g_{i}}^{2}, \ldots \ldots \ldots . . ., M_{g_{i}}^{m}, i=1,2, \ldots, n
$$

Where,$M_{g_{i}}^{j}(j=1,2, \ldots, m)$ are all TFNs.

Next, the value of fuzzy extent with respect to the $i^{\text {th }}$ object is obtained by:

$$
S_{i}=\sum_{j=1}^{m} M_{g_{i}}^{j} \otimes\left[\sum_{i=1}^{n} \sum_{j=1}^{m} M_{g_{i}}^{j}\right]^{-1}
$$

In order to obtain $\sum_{j=1}^{m} M_{g_{i}}^{j}$, the fuzzy addition operations need to be performed as given below:

$$
\sum_{j=1}^{m} M_{g_{i}}^{j}=\left(\sum_{j=1}^{m} p_{j}, \sum_{j=1}^{m} q_{j}, \sum_{j=1}^{m} r_{j}\right)
$$

To obtain

$$
\left[\sum_{J=1}^{n} \sum_{j=1}^{m} M_{g_{i}}^{j}\right]^{-1}
$$

It is necessary to perform the fuzzy addition operation with $M_{g_{i}}^{j}(j=1,2 \ldots, m)$ values.

$$
\sum_{i=1}^{n} \sum_{j=1}^{m} M_{g_{i}}^{j}=\left(\sum_{i=1}^{n} p_{i}, \sum_{i=1}^{n} q_{i}, \sum_{i=1}^{n} r_{i}\right)
$$

Then, inverse of the identified vector is calculated by substituting the values in Eq. (8), so that

$$
\left[\sum_{i=1}^{n} \sum_{j=1}^{m} M_{g_{i}}^{j}\right]^{-1}=\left[1 / \sum_{i=1}^{n} r_{i}, 1 / \sum_{i=1}^{n} q_{i}, 1 / \sum_{j=1}^{m} p_{j}\right]
$$

The degree of possibilities of $M_{2}=\left(p_{2}, q_{2}, r_{2}\right) \geq M_{1}=\left(p_{1}, q_{1}, r_{1}\right)$ is defined as:

$$
\mathrm{V}\left(M_{2} \geq M_{1}\right)=\sup _{y \geq x}\left[\min \left(\mu_{M_{1}}(x), \mu_{M_{2}}(y)\right)\right]
$$


This can be expressed as follows:

$$
\begin{aligned}
& \mathrm{V}\left(M_{2} \geq M_{1}\right)=\operatorname{hgt}\left(M_{1} \cap M_{2}\right)=\mu_{M_{2}}(d) \\
& =\left\{\begin{array}{cr}
1 & \text { if } q_{2} \geq q_{1} \\
0 & \text { if } p_{2} \geq r_{2} \\
p_{1}-r_{2} /\left(q_{2}-r_{2}\right)-\left(q_{1}-p_{1}\right) & \text { otherwise }
\end{array}\right.
\end{aligned}
$$

Fig.2 illustrates the intersection between two TFNs where $d$ is the ordinate of the highest intersection point $D$ between $\mu_{M_{1}}$ and $\mu_{M_{2}}$. To compare $M_{1}$ and $M_{2}$, we need both the values $\operatorname{ofV}\left(M_{2} \geq M_{1}\right) \operatorname{andV}\left(M_{1} \geq M_{2}\right)$.

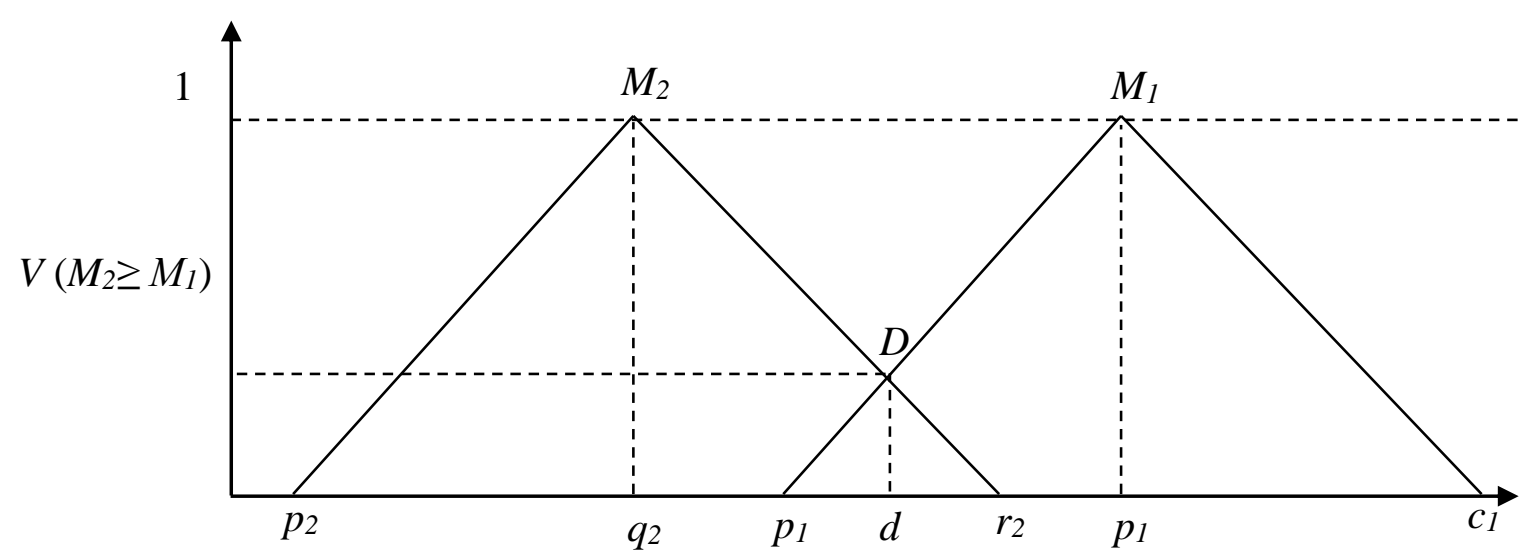

Fig.2 Intersection between $M_{2}$ and $M_{1}$.

A fuzzy number is a special case of a convex, normalized fuzzy set of the real line (Zadeh, 1965). A fuzzy set is convex if

$A(t x+(1-t) y) \geq \min (A(x), A(y))$ for $\mathrm{x}, \mathrm{y} \in \mathbb{R}^{n}, \mathrm{t} \in(0,1)$. Therefore, using this property of fuzzy set, the degree of possibilities for a convex fuzzy number to be greater than $k$ convex fuzzy $M_{i}(i=1,2, \ldots k)$ is defined by:

$$
\begin{gathered}
\mathrm{V}\left(M \geq M_{1}, M_{2}, \ldots ., M_{k}\right)=\mathrm{V}\left[\left(M \geq M_{1}\right) \text { and }\left(M \geq M_{2}\right)\right. \text { and } \\
\left.\left(M \geq M_{k}\right)\right]=\min \mathrm{V}\left(M \geq M_{i}\right), i=1,2,3, \ldots, k
\end{gathered}
$$

Assume that $d^{\prime}\left(A_{i}\right)=\min \mathrm{V}\left(S_{i} \geq S_{k}\right)$ for $k=1,2, \ldots, n ; k \neq i$. Then the weight vector is given by:

$$
W^{\prime}=\left(d^{\prime}\left(A_{1}\right), d^{\prime}\left(A_{2}\right), \ldots, d^{\prime}\left(A_{n}\right)\right)^{T},
$$

where $A_{i}(i=1,2, \ldots, n)$ are $n$ elements.

Step 4: The normalized weights are:

$$
W=\left(d\left(A_{1}\right), d\left(A_{2}\right), \ldots, d\left(A_{n}\right)\right)^{T}
$$

where $W$ is a non-fuzzy number. This gives the priority weights of one alternative over another. 


\section{An example}

This work conducts an arbitrary example of organisational pharmaceutical value chain; the problem is to manage risks in implementing GSC initiatives in the pharmaceutical sector in India. In addition, the example organisational pharmaceutical value chain is considered as a part of 'Sustainable Development of Health Sector' and has a goal to adopt GSC concepts to improve its business sustainability. However, it is important to manage risks in integrating green concepts in the industry value chains, and therefore, a panel of four experts (one warehouse manager, one supply chain professional, one operations manager and one environmental engineer) was formed. The experts were very competitive in operations, supply chain management and risks management; each was involved with the planned (phased) methodology as follows:

\subsection{Phase 1: Finalisation of risks}

Forty two risks related to the implementation of GSC initiatives in the pharmaceutical industry were identified from current literature. In order to deal with vagueness in finalizing the risks, fuzzy Delphi method is employed. The experts from the panel were contacted to check the suitability of listed risks to GSC initiatives in the pharmaceutical industry in India. A questionnaire (phase1 questionnaire in Appendix A) was prepared and developed. The judgement of experts was captured using a scale shown in Table 2.

Table 2. Linguistic scale used in this work

\begin{tabular}{ll}
\hline Linguistics & Fuzzy number \\
\hline Very Low & $(0,0,0.1)$ \\
Low & $(0,0.1,0.3)$ \\
Medium Low & $(0.1,0.3,0.5)$ \\
Medium & $(0.3,0.5,0.7)$ \\
Medium High & $(0.5,0.7,0.9)$ \\
High & $(0.7,0.9,1.0)$ \\
Very High & $(0.9,1.0,1.0)$ \\
\hline
\end{tabular}

According to fuzzy Delphi procedure, the expert's fuzzy inputs are defuzzified to obtain crisp values. The results of the fuzzy Delphi technique are shown in Table 3. Based on previous studies and consultation with experts, a threshold value $r=0.60$ is set to decide the inclusion or exclusion of particular risk (Shen et al., 2010; Kumar et al., 2017). The risks having threshold value $>0.60$ are selected $(\mathrm{S})$; otherwise they are rejected from the list. 
Table 3. Fuzzy Delphi method analysis for finalizing risks

\begin{tabular}{|c|c|c|c|}
\hline Risks & Fuzzy Weight & Defuzzification & $\mathbf{S} / \mathbf{R}$ \\
\hline 1 & $0.10,0.74,1.00$ & 0.613 & $\mathrm{~S}$ \\
\hline 2 & $0.00,0.54,1.00$ & 0.513 & $\mathrm{~S}$ \\
\hline 3 & $0.10,0.71,1.00$ & 0.603 & $\mathrm{~S}$ \\
\hline 4 & $0.10,0.60,1.00$ & 0.516 & $\mathrm{R}$ \\
\hline 5 & $0.50,0.70,0.90$ & 0.866 & $S$ \\
\hline 6 & $0.10,0.58,1.00$ & 0.558 & $\mathrm{R}$ \\
\hline 7 & $0.30,0.76,1.00$ & 0.687 & $\mathrm{~S}$ \\
\hline 8 & $0.10,0.70,1.00$ & 0.600 & $\mathrm{~S}$ \\
\hline 9 & $0.10,0.60,1.00$ & 0.566 & $\mathrm{R}$ \\
\hline 10 & $0.50,0.70,0.90$ & 0.700 & $S$ \\
\hline 11 & $0.70,0.90,1.00$ & 0.866 & $\mathrm{~S}$ \\
\hline 12 & $0.10,0.71,1.00$ & 0.604 & $S$ \\
\hline 13 & $0.10,0.50,1.00$ & 0.533 & $\mathrm{R}$ \\
\hline 14 & $0.30,0.70,1.00$ & 0.666 & $\mathrm{~S}$ \\
\hline 15 & $0.50,0.70,0.90$ & 0.700 & $\mathrm{~S}$ \\
\hline 16 & $0.00,0.51,1.00$ & 0.504 & $\mathrm{R}$ \\
\hline 17 & $0.10,0.55,0.90$ & 0.517 & $\mathrm{R}$ \\
\hline 18 & $0.30,0.71,1.00$ & 0.671 & $\mathrm{~S}$ \\
\hline 19 & $0.10,0.69,1.00$ & 0.596 & $\mathrm{R}$ \\
\hline 20 & $0.30,0.60,0.90$ & 0.600 & $S$ \\
\hline 21 & $0.30,0.73,1.00$ & 0.675 & $S$ \\
\hline 22 & $0.50,0.81,1.00$ & 0.771 & $S$ \\
\hline 23 & $0.30,0.61,1.00$ & 0.637 & $\mathrm{~S}$ \\
\hline 24 & $0.30,0.73,1.00$ & 0.675 & $S$ \\
\hline 25 & $0.00,0.55,1.00$ & 0.517 & $\mathrm{R}$ \\
\hline 26 & $0.30,0.53,0.90$ & 0.575 & $\mathrm{R}$ \\
\hline 27 & $0.10,0.58,1.00$ & 0.558 & $\mathrm{R}$ \\
\hline 28 & $0.30,0.71,1.00$ & 0.671 & $S$ \\
\hline 29 & $0.00,0.45,0.90$ & 0.450 & $\mathrm{R}$ \\
\hline 30 & $0.70,0.90,1.00$ & 0.867 & $S$ \\
\hline 31 & $0.30,0.79,1.00$ & 0.696 & $S$ \\
\hline 32 & $0.00,0.45,0.90$ & 0.450 & $\mathrm{R}$ \\
\hline 33 & $0.70,0.90,1.00$ & 0.867 & $S$ \\
\hline 34 & $0.70,0.90,1.00$ & 0.867 & $S$ \\
\hline 35 & $0.70,0.90,1.00$ & 0.867 & $S$ \\
\hline 36 & $0.30,0.74,1.00$ & 0.679 & $S$ \\
\hline 37 & $0.30,0.71,1.00$ & 0.571 & $\mathrm{R}$ \\
\hline 38 & $0.30,0.68,1.00$ & 0.658 & $S$ \\
\hline 39 & $0.30,0.66,1.00$ & 0.654 & $\mathrm{~S}$ \\
\hline 40 & $0.30,0.68,1.00$ & 0.658 & $S$ \\
\hline 41 & $0.10,0.60,1.00$ & 0.567 & $\mathrm{R}$ \\
\hline 42 & $0.10,0.53,1.00$ & 0.542 & $\mathrm{R}$ \\
\hline
\end{tabular}

Note: S- Selected and $R$ - Rejected

The experts were also asked to include any risk which they think is the most suitable to GSC initiatives in the pharmaceutical industry. However, they did not suggest any other 
modifications and were satisfied with fuzzy Delphi procedure in finalizing the risks. Hence, twenty-six risks are listed in this work; these were further classified into seven categories through expert feedback. The categories include - operational risks, supply risks, product recovery risks, financial risks, government and organisational risks, environmental risks and cold chain technology risks. Then, priority weights for risks and their respective categories are computed.

\subsection{Phase 2: Computation of priority weights of risks}

The priority weights of finalized risks are computed using fuzzy AHP. Initially, the expert panel is consulted to develop a hierarchy model of risks as shown in Fig.3. There are three levels in this hierarchy model - prioritising the risks in adopting GSC initiatives in pharmaceutical industry (level 1- goal set); categories of risks (level 2 - criteria); sub-risks (level 3 - sub-criteria).

Experts were then asked to frame pair wise assessment matrices for the risks and their respective categories. The expert responses are recorded using Saaty's 1-9 scale (refer to phase 2 of questionnaire as provided in Appendix A). The pair-wise assessment for categories of risks as made by the expert panel (total of 4 experts) is shown below:

$$
\begin{aligned}
\mathrm{E}^{1} & =\left[\begin{array}{lllllll}
1 & 3 & 5 & 5 & 5 & 3 & 1 / 3 \\
1 / 3 & 1 & 3 & 5 & 5 & 3 & 1 / 5 \\
1 / 5 & 1 / 3 & 1 & 1 / 3 & 3 & 3 & 1 / 5 \\
1 / 5 & 1 / 5 & 3 & 1 & 3 & 3 & 1 / 5 \\
1 / 5 & 1 / 5 & 1 / 3 & 1 / 3 & 1 & 3 & 1 / 7 \\
1 / 3 & 1 / 3 & 1 / 3 & 1 / 3 & 1 / 3 & 1 & 1 / 7 \\
3 & 5 & 5 & 5 & 7 & 7 & 1
\end{array}\right], \mathrm{E}^{2}=\left[\begin{array}{lllllll}
1 & 1 / 5 & 3 & 3 & 5 & 1 & 1 / 7 \\
5 & 1 & 3 & 3 & 5 & 3 & 1 / 5 \\
1 / 3 & 1 / 3 & 1 & 1 / 3 & 1 / 3 & 1 / 7 & 1 / 5 \\
1 / 3 & 1 / 3 & 3 & 1 & 1 / 3 & 1 / 3 & 1 / 7 \\
1 / 5 & 1 / 5 & 3 & 3 & 1 & 1 / 5 & 1 / 7 \\
1 & 1 / 3 & 7 & 3 & 5 & 1 & 1 / 7 \\
7 & 5 & 5 & 7 & 7 & 7 & 1
\end{array}\right], \\
\mathrm{E}^{3} & =\left[\begin{array}{lllllll}
1 & 3 & 3 & 5 & 3 & 1 & 1 / 3 \\
1 / 3 & 1 & 5 & 5 & 5 & 1 & 1 / 5 \\
1 / 3 & 1 / 5 & 1 & 1 / 3 & 1 / 3 & 1 / 5 & 1 / 5 \\
1 / 5 & 1 / 5 & 3 & 1 & 1 & 1 / 3 & 1 / 5 \\
1 / 3 & 1 / 5 & 3 & 1 & 1 & 1 / 3 & 1 / 3 \\
1 & 1 & 5 & 3 & 3 & 1 & 1 / 3 \\
3 & 5 & 5 & 5 & 3 & 3 & 1
\end{array}\right], \mathrm{E}^{4}=\left[\begin{array}{lllllll}
1 & 1 & 3 & 5 & 5 & 1 / 3 & 1 / 3 \\
1 & 1 & 3 & 3 & 3 & 1 & 3 \\
1 / 3 & 1 / 3 & 1 & 1 / 3 & 3 & 1 / 3 & 1 / 7 \\
1 / 5 & 1 / 3 & 3 & 1 & 3 & 1 / 3 & 1 / 3 \\
1 / 5 & 1 / 3 & 1 / 3 & 1 / 3 & 1 & 1 / 5 & 1 / 7 \\
3 & 1 & 3 & 3 & 5 & 1 & 1 / 5 \\
3 & 3 & 7 & 3 & 7 & 5 & 1
\end{array}\right]
\end{aligned}
$$




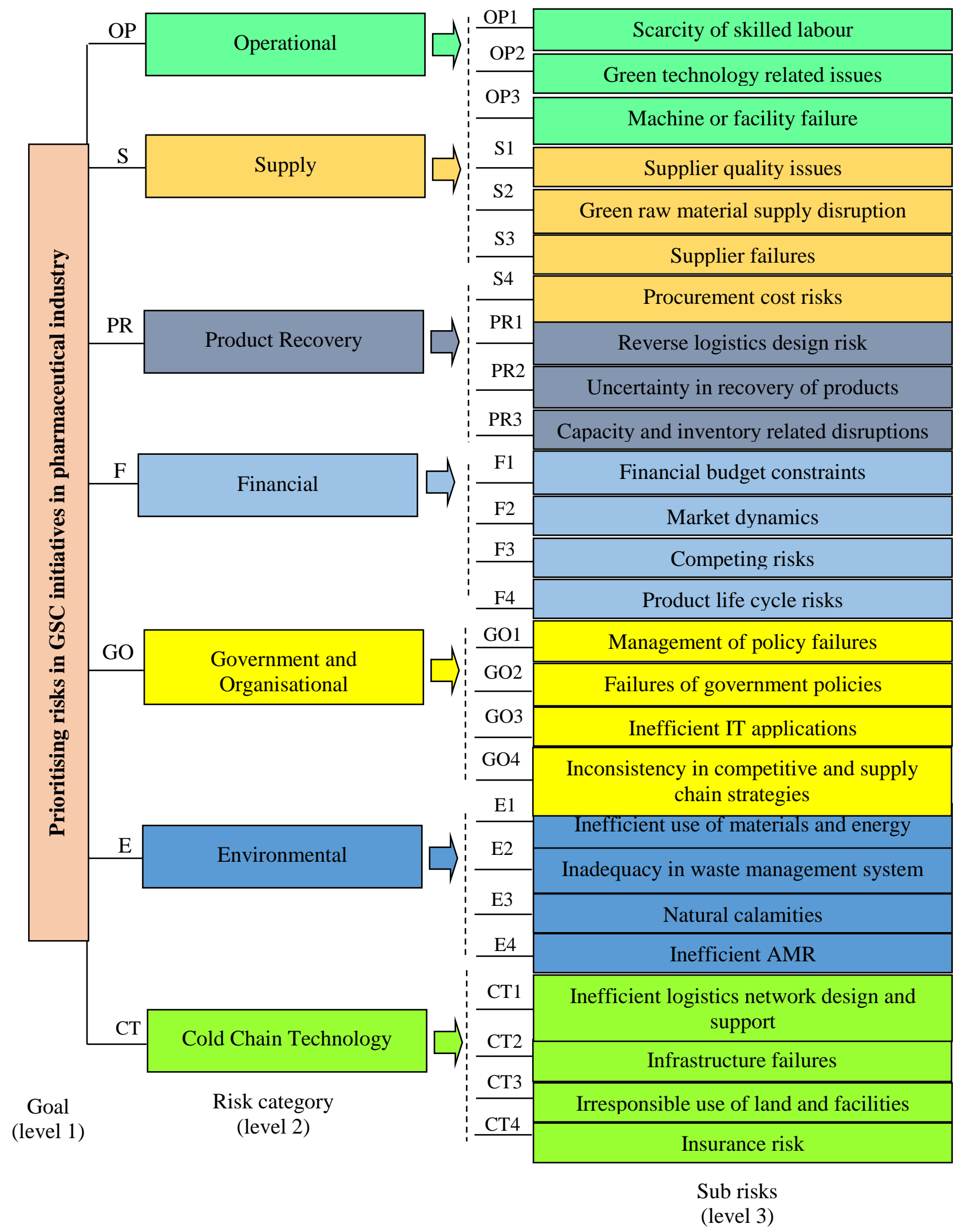

Fig.3 A hierarchy model of final selected risks 
By using Eq. (5), the expert panel inputs are combined to develop a fuzzy matrix as shown in

Table 4. A sample calculation in developing entry for the fuzzy matrix when operational risk is compared with supply risk is illustrated where $k$ represents total number of decision makers.

For instance, $\left(\tilde{x}_{12}\right)=\left(a_{12}, b_{12}, c_{12}\right)=(0.20,1.80,3.00)$ as follows:

$$
\begin{aligned}
& a_{12}=\min _{k=1 \text { to } 4}\left(a_{i j k}\right)=\min \left(a_{121}, a_{122}, a_{123}, a_{124}\right)=(3,1 / 5,3,1)=1 / 5=0.20 \\
& b_{12}=\frac{1}{4} * \sum_{k=1}^{K}\left(a_{i j k}\right)=\frac{1}{4}\left(a_{121}+a_{122}+a_{123}+a_{124}\right)=\frac{1}{4}(3+1 / 5+3+1)=1.80 \\
& c_{12}=\max _{k=1 \text { to } 4}\left(a_{i j k}\right)=\max \left(a_{121}, a_{122}, a_{123}, a_{124}\right)=(3,1 / 5,3,1)=3=3
\end{aligned}
$$

Table 4. Fuzzy pairwise comparison matrix

\begin{tabular}{|c|c|c|c|c|c|c|c|}
\hline & OP & $\mathrm{S}$ & $\mathrm{PR}$ & $\mathrm{F}$ & $\mathrm{GO}$ & $\mathrm{E}$ & $\mathrm{CT}$ \\
\hline OP & $(1,1,1)$ & $(0.20,1.80$, & $(3.00,3.50$, & $(3.00,4.50$, & $(3.00,4.50$, & $(0.33,1.33$, & $(0.14,0.29$, \\
& & $3.00)$ & $5.00)$ & $5.00)$ & $5.00)$ & $3.00)$ & $0.33)$ \\
\hline S & $(0.33,1.67$, & $(1,1,1)$ & $(3.00,3.50$, & $(3.00,4.00$, & $(3.00,4.50$, & $(1.00,2.00$, & $(0.20,0.23$, \\
& $5.00)$ & & $5.00)$ & $5.00)$ & $5.00)$ & $3.00)$ & $0.33)$ \\
\hline PR & $(0.20,0.30$, & $(0.20,0.30$, & $((1,1,1)$ & $(0.33,0.33$, & $(0.33,1.67$, & $(0.14,0.92$, & $(0.14,0.19$, \\
& $0.33)$ & $0.33)$ & & 0.33 & $3.00)$ & $3.00)$ & $0.20)$ \\
\hline F & $(0.20,0.23$, & $(0.20,0.26$, & $(3.00,3.00$, & $(1,1,1)$ & $(0.33,1.83$, & $(0.33,0.99$, & $(0.14,0.22$, \\
& $0.33)$ & $0.33)$ & $3.00)$ & & $3.00)$ & $3.00)$ & $0.33)$ \\
\hline GO & $(0.20,0.23$, & $(0.11,1.17$, & $(0.33,1.67$, & $(0.33,1.17$, & $(1,1,1)$ & $(0.20,0.93$, & $(0.14,0.19$, \\
& $0.33)$ & $3.00)$ & $3.00)$ & $3.00)$ & & $1.00)$ & $0.33)$ \\
\hline E & $(0.33,1.33$, & $(0.33,0.67$, & $(0.33,3.83$, & $(0.33,2.33$, & $(0.33,3.33$, & $(1,1,1)$ & $(0.14,0.20$, \\
& $3.00)$ & $1.00)$ & $7.00)$ & $3.00)$ & $5.00)$ & & $0.33)$ \\
\hline CT & $(3.00,4.00$, & $(3.00,4.50$, & $(5.00,5.50$, & $(3.00,5.00$, & $(3.00,6.00$, & $(3.00,5.50$, & $(1,1,1)$ \\
& $7.00)$ & $5.00)$ & $7.00)$ & $7.00)$ & $7.00)$ & $7.00)$ & \\
\hline & $(1.00,1.00$, & $(0.20,1.80$, & $(3.00,3.50$, & $(3.00,4.50$, & $(3.00,4.50$, & $(0.33,1.33$, & $(0.14,0.29$, \\
& $1.00)$ & $3.00)$ & $5.00)$ & $5.00)$ & $5.00)$ & $3.00)$ & $0.33)$ \\
\hline
\end{tabular}

Next, the weights of categories of risks are computed using extent analysis method. A sample calculation for computing the weights of categories of risks is provided in Appendix B. Table 5 shows the priority weight of categories of risks along with their ranking.

Table 5.Ranking of categories of risks

\begin{tabular}{lll}
\hline $\begin{array}{l}\text { Risk } \\
\text { categories }\end{array}$ & Weight & Ranking \\
\hline OP & 0.19 & 3 \\
S & 0.21 & 2 \\
PR & 0.01 & 7 \\
F & 0.05 & 5 \\
GO & 0.04 & 6 \\
E & 0.17 & 4 \\
CT & 0.33 & 1 \\
\hline
\end{tabular}


The 'cold chain technology' category of risks obtained the topmost weight, followed by supply risks, operational risks, environmental risks, financial risks, government and organisational risk then product recovery risks. In the same way, the weights of risks within the categories are also computed. The relative priority weights and global weights of each risk are calculated along with their rank as shown in Table 6.

Table 6. Final ranking of risks

\begin{tabular}{llllll}
\hline $\begin{array}{l}\text { Risk } \\
\text { category }\end{array}$ & Sub-risks & $\begin{array}{l}\text { Local } \\
\text { priorities }\end{array}$ & $\begin{array}{l}\text { Local } \\
\text { ranking }\end{array}$ & $\begin{array}{l}\text { Global } \\
\text { priorities }\end{array}$ & $\begin{array}{l}\text { Global } \\
\text { ranking }\end{array}$ \\
\hline OP & OP1 & 0.33 & 3 & 0.063 & 6 \\
& OP2 & 0.57 & 1 & 0.108 & 4 \\
S & OP3 & 0.10 & 2 & 0.019 & 15 \\
& S1 & 0.20 & 2 & 0.042 & 9 \\
& S2 & 0.56 & 1 & 0.118 & 2 \\
& S3 & 0.15 & 3 & 0.032 & 11 \\
PR & S4 & 0.09 & 4 & 0.019 & 17 \\
& PR1 & 0.38 & 2 & 0.004 & 24 \\
& PR2 & 0.13 & 3 & 0.001 & 26 \\
F & PR3 & 0.48 & 1 & 0.005 & 22 \\
& F1 & 0.43 & 1 & 0.022 & 14 \\
& F2 & 0.11 & 3 & 0.006 & 20 \\
& F3 & 0.09 & 4 & 0.005 & 23 \\
GO & F4 & 0.38 & 2 & 0.019 & 15 \\
& GO1 & 0.26 & 2 & 0.010 & 19 \\
& GO2 & 0.55 & 1 & 0.022 & 13 \\
& GO3 & 0.07 & 4 & 0.003 & 25 \\
E & GO4 & 0.13 & 3 & 0.005 & 21 \\
& E1 & 0.44 & 1 & 0.075 & 5 \\
& E2 & 0.34 & 2 & 0.058 & 7 \\
& E3 & 0.08 & 4 & 0.014 & 18 \\
& E4 & 0.15 & 3 & 0.026 & 12 \\
CT & CT1 & 0.35 & 2 & 0.116 & 3 \\
& CT2 & 0.40 & 1 & 0.132 & 1 \\
& CT3 & 0.14 & 3 & 0.046 & 8 \\
& CT4 & 0.11 & 4 & 0.036 & 10 \\
\hline
\end{tabular}

Table 6 shows the global priority ranks of all sub-risks. The result shows that the infrastructure failures (CT2) risk is most prioritised, while the uncertainty recovery of products (PR2) risk took up last position.

\subsection{Sensitivity analysis}

The sensitivity analysis is considered to be an essential component to validate any developed framework or model (Mangla et al., 2015a; Gupta and Barua, 2017). It is important to 
identify how a particular model will behave under different working environments (Bai and Sarkis, 2014). Various researchers (Mangla et al., 2017; Yadav et al., 2018) have used sensitivity analysis as a tool to validate the framework developed; hence for the present case changes in experts' inputs are considered while conducting the sensitivity analysis.

The risk 'cold chain technology (CT)'is most prioritised risk and supply (S) is the second highest risk; this implies that a slight change in weights of these risks may influence the other risks significantly. Accordingly, a natural method is to change the considered factor proportionally - as considered in this work for the sensitivity analysis. Therefore, cold chain technology risks weights are changed from $0.33(\mathrm{CT})$ to $(0.33 * 0.9=\mathbf{0 . 3 0}, 0.33 * 0.8=\mathbf{0 . 2 6}$, $0.33 * 0.7=\mathbf{0 . 2 3}, 0.33 * 0.6=\mathbf{0 . 2 0}, 0.33 * 0.5=\mathbf{0 . 1 7}, 0.33 * 0.4=\mathbf{0 . 1 3}, 0.33 * 0.3=\mathbf{0 . 1 0}, 0.33 * 0.2$ $=\mathbf{0 . 0 7}$ and $0.33 * 0.1=\mathbf{0 . 0 3}$, values are considered to two decimal places). After this change the variation was observed in other risks. The sensitivity analysis shows that maximum change occurs in 'operational risk' category (see Table 7). The ranking for specific risks also changes accordingly, as shown in Table 8. Additionally, the results of sensitivity analysis are also plotted graphically as shown in Fig.4. According to Fig. 4, the priority ranking of the sub-risks also varies with respect to changes in the weights of categories of risks.

Table 7. Risk values when increasing cold chain technology (CT) risk values

\begin{tabular}{|c|c|c|c|c|c|c|c|c|c|c|}
\hline Risk categories & Normal & \multicolumn{10}{|c|}{ Increment changes } \\
\hline OP & 0.19 & 0.20 & 0.21 & 0.22 & 0.23 & 0.24 & 0.25 & 0.26 & 0.26 & 0.27 \\
\hline S & 0.21 & 0.22 & 0.23 & 0.24 & 0.25 & 0.26 & 0.27 & 0.28 & 0.29 & 0.30 \\
\hline PR & 0.01 & 0.01 & 0.01 & 0.01 & 0.01 & 0.01 & 0.01 & 0.01 & 0.01 & 0.01 \\
\hline F & 0.05 & 0.05 & 0.05 & 0.06 & 0.06 & 0.06 & 0.06 & 0.07 & 0.07 & 0.07 \\
\hline GO & 0.04 & 0.04 & 0.04 & 0.05 & 0.05 & 0.05 & 0.05 & 0.05 & 0.06 & 0.06 \\
\hline E & 0.17 & 0.18 & 0.19 & 0.20 & 0.20 & 0.21 & 0.22 & 0.23 & 0.24 & 0.25 \\
\hline CT & 0.33 & $\mathbf{0 . 3 0}$ & $\mathbf{0 . 2 6}$ & $\mathbf{0 . 2 3}$ & $\mathbf{0 . 2 0}$ & $\mathbf{0 . 1 7}$ & $\mathbf{0 . 1 3}$ & $\mathbf{0 . 1 0}$ & $\mathbf{0 . 0 7}$ & $\mathbf{0 . 0 3}$ \\
\hline
\end{tabular}

Table 8. Sensitivity analysis of sub-risks with ' $\mathrm{CT}$ ' risk changes from $(0.33 * 0.9 \ldots 0.33 * 0.1)$

\begin{tabular}{|c|c|c|c|c|c|c|c|c|c|c|}
\hline & $\begin{array}{c}\text { CT = } \\
\text { (Normal) }\end{array}$ & $\begin{array}{c}\text { CT= } \\
\mathbf{0 . 3 0}\end{array}$ & $\begin{array}{c}\text { CT= } \\
\mathbf{0 . 2 6}\end{array}$ & $\begin{array}{c}\text { CT= } \\
\mathbf{0 . 2 3}\end{array}$ & $\begin{array}{c}\text { CT= } \\
\mathbf{0 . 2 0}\end{array}$ & $\begin{array}{c}\text { CT= }= \\
\mathbf{0 . 1 7}\end{array}$ & $\begin{array}{c}\text { CT= }= \\
\mathbf{0 . 1 3}\end{array}$ & $\begin{array}{c}\text { CT= }= \\
\mathbf{0 . 1 0}\end{array}$ & $\begin{array}{c}\text { CT= }= \\
\mathbf{0 . 0 7}\end{array}$ & $\begin{array}{c}\text { CT= } \\
\mathbf{0 . 0 3}\end{array}$ \\
\hline OP1 & 6 & 6 & 6 & 6 & 5 & 4 & 4 & 4 & 4 & 4 \\
\hline OP2 & 4 & 3 & 2 & 2 & 2 & 2 & 2 & 2 & 2 & 2 \\
\hline OP3 & 15 & 16 & 15 & 16 & 14 & 13 & 14 & 13 & 11 & 11 \\
\hline S1 & 9 & 8 & 8 & 8 & 8 & 8 & 6 & 6 & 6 & 6 \\
\hline S2 & 2 & 1 & 1 & 1 & 1 & 1 & 1 & 1 & 1 & 1 \\
\hline S3 & 11 & 10 & 10 & 9 & 9 & 9 & 9 & 7 & 7 & 7 \\
\hline S4 & 17 & 17 & 17 & 17 & 16 & 15 & 15 & 15 & 14 & 13 \\
\hline PR1 & 24 & 24 & 24 & 24 & 24 & 24 & 24 & 24 & 24 & 22 \\
\hline PR2 & 26 & 26 & 26 & 26 & 26 & 26 & 26 & 26 & 26 & 26 \\
\hline PR3 & 22 & 22 & 22 & 22 & 22 & 22 & 22 & 22 & 22 & 20 \\
\hline F1 & 14 & 14 & 14 & 14 & 13 & 12 & 12 & 12 & 10 & 10 \\
\hline
\end{tabular}




\begin{tabular}{|c|c|c|c|c|c|c|c|c|c|c|}
\hline F2 & 20 & 20 & 20 & 20 & 20 & 20 & 20 & 20 & 19 & 18 \\
\hline F3 & 23 & 23 & 23 & 23 & 23 & 23 & 23 & 23 & 23 & 21 \\
\hline F4 & 15 & 15 & 15 & 15 & 14 & 13 & 13 & 13 & 11 & 12 \\
\hline GO1 & 19 & 19 & 19 & 19 & 19 & 19 & 19 & 17 & 17 & 15 \\
\hline GO2 & 13 & 13 & 13 & 13 & 12 & 11 & 11 & 11 & 9 & 9 \\
\hline GO3 & 25 & 25 & 25 & 25 & 25 & 25 & 25 & 25 & 25 & 24 \\
\hline GO4 & 21 & 21 & 21 & 21 & 21 & 21 & 21 & 21 & 21 & 19 \\
\hline E1 & 5 & 5 & 5 & 4 & 3 & 3 & 3 & 3 & 3 & 3 \\
\hline E2 & 7 & 7 & 7 & 7 & 7 & 5 & 5 & 5 & 5 & 5 \\
\hline E3 & 18 & 18 & 18 & 18 & 18 & 18 & 17 & 16 & 16 & 14 \\
\hline E4 & 12 & 12 & 12 & 11 & 10 & 10 & 10 & 10 & 8 & 8 \\
\hline CT1 & 3 & 4 & 4 & 5 & 6 & 7 & 8 & 9 & 15 & 17 \\
\hline CT2 & 1 & 2 & 3 & 3 & 4 & 6 & 7 & 8 & 13 & 16 \\
\hline CT3 & 8 & 9 & 9 & 10 & 11 & 16 & 16 & 18 & 18 & 23 \\
\hline CT4 & 10 & 11 & 11 & 12 & 17 & 17 & 18 & 19 & 20 & 25 \\
\hline
\end{tabular}

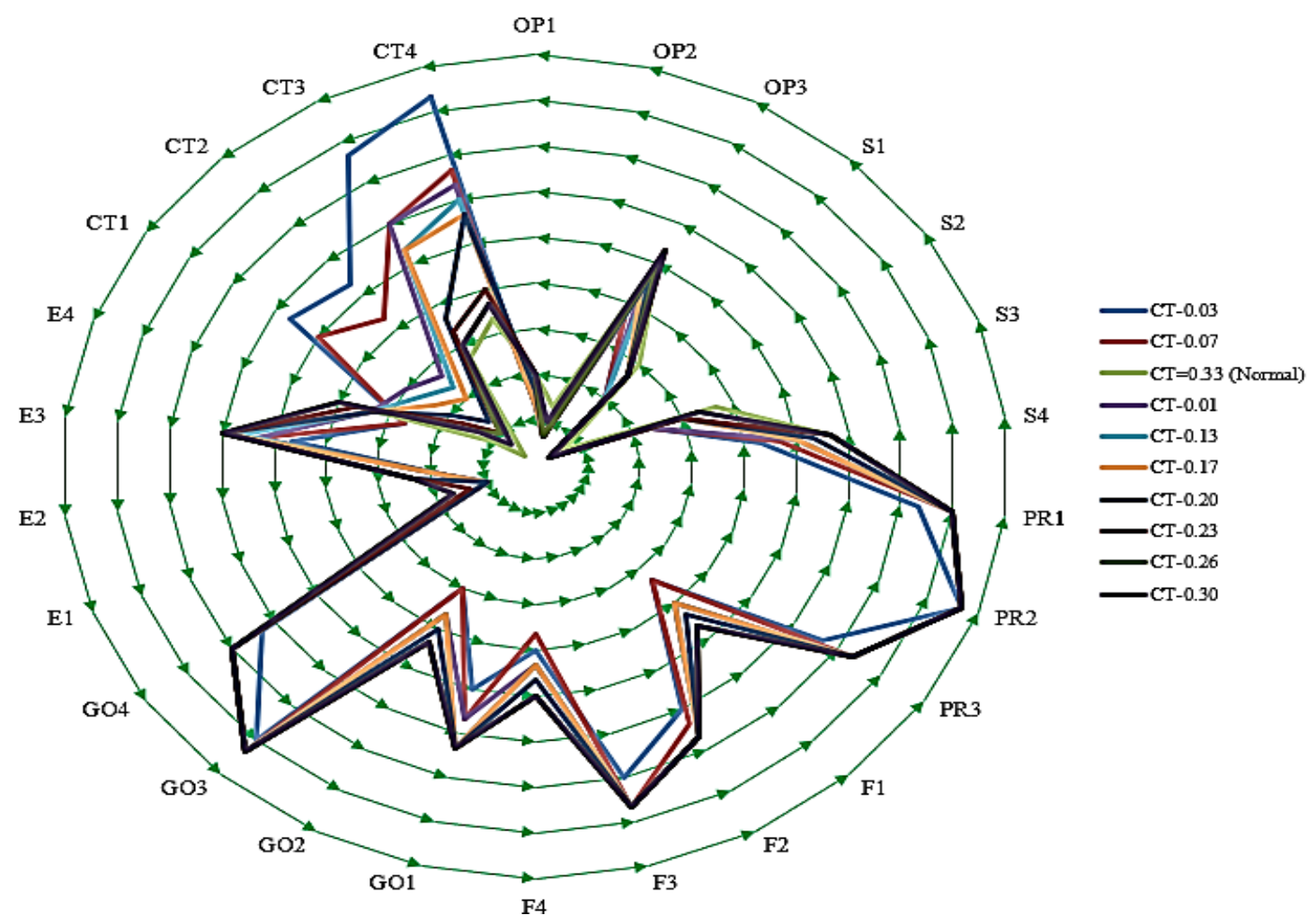

Fig. 4. Result of sensitivity anlaysis for cold chain technology (CT) risk

The same procedure is followed for the second highest risk named 'supply (S)'; the results are shown in Tables 9-10 and graphically represented in Fig.5. The supply risk weights are changed from $0.21(\mathrm{~S})$ to $(0.21 * 0.9=\mathbf{0 . 1 9}, 0.21 * 0.8=\mathbf{0 . 1 7}, 0.21 * 0.7=\mathbf{0 . 1 5}, 0.21 * 0.6=$ $\mathbf{0 . 1 3}, 0.21 * 0.5=\mathbf{0 . 1 1}, 0.21 * 0.4=\mathbf{0 . 0 8}, 0.21 * 0.3=\mathbf{0 . 0 6}, 0.21 * 0.2=\mathbf{0 . 0 4}$ and $0.21 * 0.1=\mathbf{0 . 0 2}$, values are considered to two decimal places). The sensitivity analysis shows that maximum change occurs in the "cold chain technology (CT) category (see Table 10). 
Table 9. Risk values when increasing supply risk values

\begin{tabular}{|c|c|c|c|c|c|c|c|c|c|c|}
\hline Risk categories & Normal & \multicolumn{10}{|c|}{ Increment changes } \\
\hline OP & 0.19 & 0.20 & 0.20 & 0.21 & 0.21 & 0.22 & 0.22 & 0.23 & 0.23 & 0.24 \\
\hline S & 0.21 & $\mathbf{0 . 1 9}$ & $\mathbf{0 . 1 7}$ & $\mathbf{0 . 1 5}$ & $\mathbf{0 . 1 3}$ & $\mathbf{0 . 1 1}$ & $\mathbf{0 . 0 8}$ & $\mathbf{0 . 0 6}$ & $\mathbf{0 . 0 4}$ & $\mathbf{0 . 0 2}$ \\
\hline PR & 0.01 & 0.01 & 0.01 & 0.01 & 0.01 & 0.01 & 0.01 & 0.01 & 0.01 & 0.01 \\
\hline F & 0.05 & 0.05 & 0.05 & 0.05 & 0.06 & 0.06 & 0.06 & 0.06 & 0.06 & 0.06 \\
\hline GO & 0.04 & 0.04 & 0.04 & 0.04 & 0.04 & 0.05 & 0.05 & 0.05 & 0.05 & 0.05 \\
\hline E & 0.17 & 0.17 & 0.18 & 0.18 & 0.19 & 0.19 & 0.20 & 0.20 & 0.21 & 0.21 \\
\hline CT & 0.33 & 0.34 & 0.35 & 0.36 & 0.37 & 0.37 & 0.38 & 0.39 & 0.40 & 0.41 \\
\hline
\end{tabular}

Table 10. Sensitivity analysis of sub-risks the 'supply' risk changes from $(0.21 * 0.9 \ldots 0.21 * 0.1)$

\begin{tabular}{|c|c|c|c|c|c|c|c|c|c|c|}
\hline & $\begin{array}{c}\mathrm{S}=0.21 \\
(\text { Normal })\end{array}$ & $\begin{array}{c}\mathrm{S}= \\
0.19\end{array}$ & $\begin{array}{c}\mathrm{S}= \\
0.17\end{array}$ & $\begin{array}{c}\mathrm{S}=15 \\
0.15\end{array}$ & $\begin{array}{c}\mathrm{S}=13 \\
0.11\end{array}$ & $\begin{array}{c}\mathrm{S}= \\
0.08\end{array}$ & $\begin{array}{c}\mathrm{S}= \\
0.06\end{array}$ & $\begin{array}{c}\mathrm{S}= \\
0.04\end{array}$ & $\begin{array}{c}\mathrm{S}= \\
0.02\end{array}$ \\
\hline OP1 & 6 & 6 & 6 & 6 & 6 & 5 & 5 & 5 & 5 & 5 \\
\hline OP2 & 4 & 3 & 3 & 3 & 3 & 3 & 3 & 3 & 3 & 3 \\
\hline OP3 & 15 & 15 & 15 & 15 & 14 & 13 & 14 & 13 & 13 & 12 \\
\hline S1 & 9 & 9 & 10 & 10 & 11 & 15 & 15 & 16 & 17 & 22 \\
\hline S2 & 2 & 4 & 4 & 4 & 5 & 7 & 8 & 9 & 12 & 16 \\
\hline S3 & 11 & 11 & 12 & 14 & 16 & 16 & 17 & 18 & 20 & 24 \\
\hline S4 & 17 & 17 & 17 & 18 & 19 & 19 & 19 & 22 & 24 & 25 \\
\hline PR1 & 24 & 24 & 24 & 24 & 24 & 24 & 24 & 24 & 23 & 21 \\
\hline PR2 & 26 & 26 & 26 & 26 & 26 & 26 & 26 & 26 & 26 & 26 \\
\hline PR3 & 22 & 22 & 22 & 22 & 22 & 22 & 22 & 21 & 21 & 19 \\
\hline F1 & 14 & 14 & 14 & 13 & 13 & 12 & 12 & 12 & 11 & 11 \\
\hline F2 & 20 & 20 & 20 & 20 & 20 & 20 & 20 & 19 & 18 & 17 \\
\hline F3 & 23 & 23 & 23 & 23 & 23 & 23 & 23 & 23 & 22 & 20 \\
\hline F4 & 15 & 15 & 15 & 15 & 14 & 13 & 13 & 13 & 13 & 12 \\
\hline GO1 & 19 & 19 & 19 & 19 & 18 & 18 & 18 & 17 & 16 & 15 \\
\hline GO2 & 13 & 13 & 13 & 12 & 12 & 11 & 11 & 11 & 10 & 10 \\
\hline GO3 & 25 & 25 & 25 & 25 & 25 & 25 & 25 & 25 & 25 & 23 \\
\hline GO4 & 21 & 21 & 21 & 21 & 21 & 21 & 21 & 20 & 19 & 18 \\
\hline E1 & 5 & 5 & 5 & 5 & 4 & 4 & 4 & 4 & 4 & 4 \\
\hline E2 & 7 & 7 & 7 & 7 & 7 & 6 & 6 & 6 & 6 & 6 \\
\hline E3 & 18 & 18 & 18 & 17 & 17 & 17 & 16 & 15 & 15 & 14 \\
\hline E4 & 12 & 12 & 11 & 11 & 10 & 10 & 10 & 10 & 9 & 9 \\
\hline CT1 & 3 & 2 & 2 & 2 & 2 & 2 & 2 & 2 & 2 & 2 \\
\hline CT2 & 1 & 1 & 1 & 1 & 1 & 1 & 1 & 1 & 1 & 1 \\
\hline CT3 & 8 & 8 & 8 & 8 & 8 & 8 & 7 & 7 & 7 & 7 \\
\hline CT4 & 10 & 10 & 9 & 9 & 9 & 9 & 9 & 8 & 8 & 8 \\
\hline
\end{tabular}




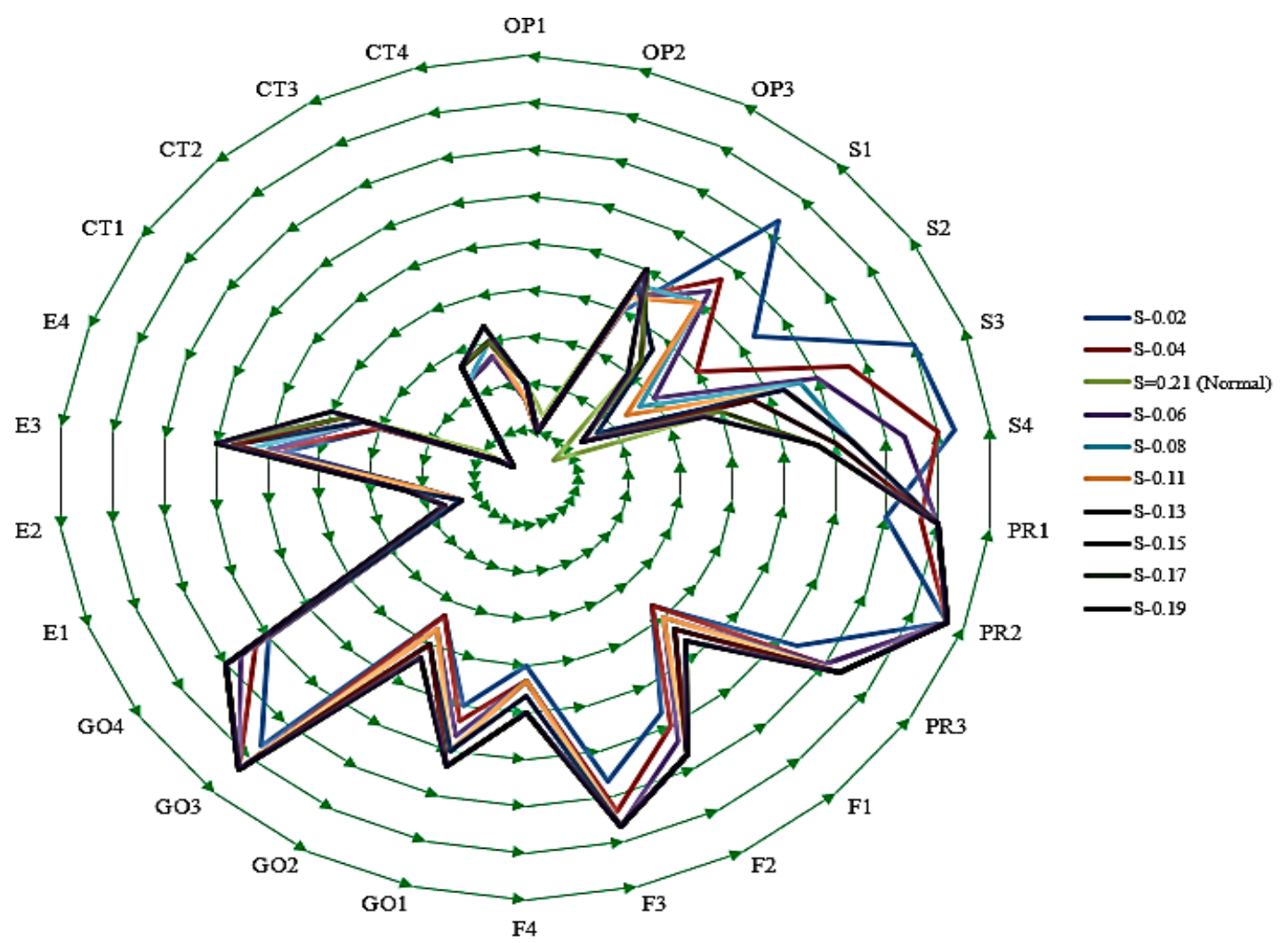

Fig. 5. Result of sensitivity anlaysis for supply risk

\section{Discussions and Insights for Managers}

The results show that the risk 'cold chain technology (CT)' has highest priority and ranked first with weight score of 0.33 . This highlights the importance of temperature-controlled technology for storage and transportation of drugs in the Indian pharmaceutical context. Cold chain technology is very important in the pharmaceutical industry where manufacturers deal with customised and sensitive products. As Jeff Luthman, vice president, life science solutions said 'Many shippers are concerned about maintaining control of products in transit'. In this category, the infrastructure failures (CT2) with weight score of 0.40 come first, followed by inefficient logistics network design and support (CT1). Since cold chain technology demands high expenditure and capital, it is hardly surprising that capital-intensive infrastructure is one of the most significant issues (Bag, 2016; Dolgui et al., 2018). Warehouses and vehicles for storage and transportation of drugs need to have an intricate temperature-monitored environment (Lintukangas et al., 2016). This also requires high insurance premiums in GSC implementation. Inefficient logistics network design and support (CT3), and insurance risks (CT4) hold third and fourth positions with weight scores of 0.14 and 0.11 respectively. 
'Supply (S)'risk category is ranked second with weight score of 0.21 . In this category, green raw material disruption (S2) holds highest priority with weight score of 0.56 . Supplier quality issues (S1) determines the workflow of the GSC in the pharmaceutical sector; it occupies the second rank among all risks. Delivering quality material is the ultimate objective of an organisation, helping to achieve both ecological and financial advantages (Luthra et al., 2011; Mohanty and Prakash, 2014). Management must select their suppliers carefully. To ensure a smooth green material supply, a good relationship with green suppliers is required (Sreedevi and Saranga, 2017; Rostamzadeh et al., 2018). Next, supplier failures (S3) hold third rank demonstrating the importance of appropriate suppliers. Procurement costs risk (S4) is ranked last in this category. In a developing country like India, managing the procurement cost is crucial. Some raw materials required for pharmaceuticals may cost ₹10,000/gram, while the availability of these chemicals is vital for production. Further, pharmaceutical companies should also collaborate with suppliers to deliver eco-friendly raw material to minimise its environmental impact. Therefore, managers should consider enhancing pharmaceutical industry effectiveness by selecting green suppliers at minimum costs.

'Operational (OP)'risk category holds third position with weight score of 0.19 . Operational risks are related to disruptions in internal operations of an organisation (Saranga and Phani, 2009; Mangla et al., 2015a). Since GSC is a relatively new concept for a developing economy like India, this makes sourcing state of the art machinery and equipment more difficult. Therefore, green technology related issues (OP2) obtain highest rank in this category followed by machine or facility failure (OP3) with weight scores of 0.57 and 0.33 respectively. Management needs to adapt to changing trends to respond to customer requests in the pharmaceutical industry in India. The workforce also needs to be educated about GSC adoption and should be trained to become skilled in operations given the risks associated with scarcity of skilled labour (OP1). This is the final specific risk in this category.

The 'environmental (E)'risks obtain fourth rank with a weight score of 0.17 . In this particular category, the risk 'inefficient use of materials and energy' (E1) ranked first. Production of pharmaceuticals products has an adverse impact on the environment. In order to manage the issues of climate change and environmental degradations, supply chain managers should devise supply chain operations and processes with minimal emissions (Jha, 2007). Hence, inadequacy in waste management system (E2) becomes highly significant in integrating GSC initiatives; it is ranked second with weight score of 0.34 . Inefficient anti-microbial resistance (E4) comes next in priority ranking. Anti-bacterial resistance is important in developing 
immunity to standard antibiotics and antivirals. Thus, it is vital to make greater investment in research and development in the pharmaceutical sector. Last in this category is natural calamity (E3). Managers must devise contingency procedures to ensure uninterrupted supplies of materials in case of any natural disaster.

'Financial (F)' risk category is ranked fifth. An inadequacy in financial resources may disrupt the implementation of GSC (Mangla et al., 2015a) in the pharmaceutical sector. The risks, expensive financial budget (F1) and product life cycle risks (F4) are the first and second rankings in this category. Next, market dynamics (F2) illustrates the uncertainties in demand for pharmaceutical products (Moktadir et al., 2018). Thus, it is important for managers to manage this risk to achieve sustainability in GSC concepts at both local and national levels. The final risk is competing risk (F3); this represents competition within the pharmaceutical industry, where companies try to maximise market share and profits.

'Governmental and organizational (GO)'risk category holds sixth position. Government policies, as well as organizational strategies (Mangla et al., 2016) have a strong influence on GSC based pharmaceutical industry design. The risk, failures of government polices (GO2) the first priority risk in this category - leads to data discrepancy and lack of continuity in government policies. Additionally, management policies need to be monitored to avoid failures - the risk management policy failures (GO1) - in accomplishing GSC objectives in the pharmaceutical industry. In order to adapt to changing supply chain practices, regular review is required from a managerial viewpoint. Management must be aware of policy implementation and directions provided by government in the healthcare industry. Next risk is inefficient IT applications (GO3). IT applications contribute to improving the knowledge and awareness about usage and dosage of medicines. This leads to a significant improvement in health care facilities in rural India (Prasad et al., 2017). The last risk in this category is inconsistency in competitive and supply chain strategies (GO4).

The 'Product recovery (PR)' risk category comes last in the list. Product recovery is significant in extracting value from used products (Mangla et al., 2015a). Capacity and inventory related issues (PR3) is the most significant risk in this category. Pharmaceutical supply managers should manage these issues in effective GSC adoption. Supply chain managers need to identify below-par products (Mangla et al., 2016) and monitor proper quality checks. This risk leads to the challenge of reverse logistics design risk (PR2), leading to huge costs to the sector. Pharmaceutical companies must pay attention to reverse logistics to enhance their effectiveness in product recovery. The pharmaceutical industry can adopt 
some initiatives from companies such as IKEA, a company known for innovation; this company allows consumers to return used products for recycling. Finally, uncertainty in recovery of pharmaceutical products (PR1) is least prioritised in this category. Pharmaceutical companies should also allow consumers to return used products for material and component recovery. Managers should frame strategies to facilitate the process of recovering the value from pharmaceutical products.

\section{Conclusions and Unique Contributions}

The pharmaceutical industry is very important in delivery life-saving products/services to society. There are many ways for pharmaceutical based materials/products/services to influence the environment; these include improper disposal of pills/tablets by patients, expired and unused medications, expulsion of pesticides and molecular farming waste, improper release of drugs by pharmacies, household sewage mixed with surplus drugs etc. This leads to higher negative environmental impact, possibly posing a question around sustainability of the pharmaceutical industry, particularly in a developing economy like India. In order to improve the environmental efficiency of pharmaceutical supply activities, the present work seeks to integrate GSC concepts in the pharmaceutical sector in the Indian context. In this sense, this work has made the following contributions:

(i) Distinguish the potential risks in adopting GSC initiatives in the pharmaceutical industry in the Indian context. This work uses literature review and fuzzy Delphi approach (with expert input) in finalizing the risks. Twenty-six risks are listed in this work; these are further classified into seven categories following expert feedback. The categories include - operational risks, supply risks, product recovery risks, financial risks, government and organizational risks, environmental risks and cold chain technology risks.

(ii) Identify the priority of these risks in effective management of the GSC initiatives in the pharmaceutical industry context. This research uses fuzzy Analytical Hierarchy Process (AHP) for prioritizing the risks under vague and unclear surroundings.

(iii) This work offers a benchmark model to company managers and government authorities in effectively developing and managing GSC initiatives in line with sustainable development goals in the pharmaceutical industry. 
According to findings, the priority order of categories of risks is given as CT- S- OP- E- FGO- PR. Similarly, the priority of sub-risks is calculated. It is evident that cold chain technology (CT) risk is of paramount importance. This result confirms the importance of temperature-controlled supply chains for storage and transportation of drugs. Companies should pay heed to this potential risk, spend the required capital and invest in resources in the most appropriate way.

This study also has some limitations. The process of identifying and finalizing the risks was very challenging. Among the identified risks, author (s) agree that some more important risks may emerge with the passage of time and developments in technology, while some risks may also become obsolete due to changes in governmental policies and regulatory structure. This work is conducted using an arbitrary organisational pharmaceutical GSC example. In future, work may be conducted using a case study and/or empirical survey based approach. This work is conducted in the Indian context; however, the benchmark framework may be applied to other developing nations to compare the outcomes. Finally, the identified risks may also be analyzed to establish their inter-relationships, using ISM, DEMATEL, ANP etc.

\section{References}

A. Narayana, S., A. Elias, A., \& K. Pati, R. (2014). Reverse logistics in the pharmaceuticals industry: a systemic analysis. The International Journal of Logistics Management, 25(2), 379-398.

Abdullah, L., \& Najib, L. (2016). Sustainable energy planning decision using the intuitionistic fuzzy analytic hierarchy process: Choosing energy technology in Malaysia. International Journal of Sustainable Energy, 35(4), 360-377.

Avikal, S., Mishra, P. K., \& Jain, R. (2014). A Fuzzy AHP and PROMETHEE method-based heuristic for disassembly line balancing problems. International Journal of Production Research, 52(5), 1306-1317.

Awasthi, A., Govindan, K., \& Gold, S. (2018). Multi-tier sustainable global supplier selection using a fuzzy AHP-VIKOR based approach. International Journal of Production Economics, 195, 106-117.

Bag, S. (2016). Modeling Barriers of Green Cold Chain Management in India. Journal of Supply Chain Management Systems, 5(1), 37-45.

Bai, C., \& Sarkis, J. (2014). Determining and applying sustainable supplier key performance indicators. Supply Chain Management: An International Journal, 19(3), 275-291.

Bhadoria, V., Bhajanka, A., Chakraborty, K., \& Mitra, P. (2012). India pharma 2020: Propelling access and acceptance, realizing true potential. McKinsey \& Co. (accessed 17 July, 2018)

Bhattacharya, A., Mohapatra, P., Kumar, V., Dey, P. K., Brady, M., Tiwari, M. K., \& Nudurupati, S. S. (2014). Green supply chain performance measurement using fuzzy ANP-based balanced scorecard: a collaborative decision-making approach. Production Planning \& Control, 25(8), 698-714. 
Bouzon, M., Govindan, K., Rodriguez, C. M. T., \& Campos, L. M. (2016). Identification and analysis of reverse logistics barriers using fuzzy Delphi method and AHP. Resources, Conservation and Recycling, 108, 182-197.

Brusset, X., \& Teller, C. (2017). Supply chain capabilities, risks, and resilience. International Journal of Production Economics, 184, 59-68.

Buckley, J. J. (1985). Fuzzy hierarchical analysis. Fuzzy sets and systems, 17(3), 233-247.

Chang, D. Y. (1996). Applications of the extent analysis method on fuzzy AHP. European journal of operational research, 95(3), 649-655.

Chang, D.-Y (1992). Extent Analysis and Synthetic Decision, Optimization Techniques and Applications, Vol. 1. World Scientific, Singapore, p. 352.

Chen, C. T., Lin, C. T., \& Huang, S. F. (2006). A fuzzy approach for supplier evaluation and selection in supply chain management. International journal of production economics, 102(2), 289-301.

Chen, C. T., Lin, C. T., \& Huang, S. F. (2006). A fuzzy approach for supplier evaluation and selection in supply chain management. International journal of production economics, 102(2), 289-301.

Chittoor, R., Ray, S., Aulakh, P. S., \& Sarkar, M. B. (2008). Strategic responses to institutional changes: 'Indigenous growth' model of the Indian pharmaceutical industry. Journal of International Management, 14(3), 252-269.

Chopra, S., Meindl, P. (2001). Supplier Chain Management. Prentice-Hall, Englewood Cliffs, NJ

Chung, C. J., \& Wee, H. M. (2011). Short life-cycle deteriorating product remanufacturing in a green supply chain inventory control system. International Journal of Production Economics, 129(1), 195203.

Dağdeviren, M., \& Yüksel, İ. (2008). Developing a fuzzy analytic hierarchy process (AHP) model for behavior-based safety management. Information sciences, 178(6), 1717-1733.

de Sousa Jabbour, A. B. L., de Oliveira Frascareli, F. C., \& Jabbour, C. J. C. (2015). Green supply chain management and firms' performance: Understanding potential relationships and the role of green sourcing and some other green practices. Resources, Conservation and Recycling, 104, 366-374.

Dolgui, A., Tiwari, M. K., Sinjana, Y., Kumar, S. K., \& Son, Y. J. (2018). Optimising integrated inventory policy for perishable items in a multi-stage supply chain. International Journal of Production Research, 56(1-2), 902-925.

Dubey, R., Gunasekaran, A., \& Papadopoulos, T. (2017). Green supply chain management: theoretical framework and further research directions. Benchmarking: An International Journal, 24(1), 184-218.

Dubois, D., \& Prade, H. (1979). Fuzzy real algebra: some results. Fuzzy sets and systems, 2(4), 327-348.

Ertuğrul, İ., \& Karakaşoğlu, N. (2008). Comparison of fuzzy AHP and fuzzy TOPSIS methods for facility location selection. The International Journal of Advanced Manufacturing Technology, 39(7-8), 783795.

Ertuğrul, İ., \& Karakaşoğlu, N. (2009). Performance evaluation of Turkish cement firms with fuzzy analytic hierarchy process and TOPSIS methods. Expert Systems with Applications, 36(1), 702-715. 
Faisal, M. (2016). Research Analysis on Barriers to Green Supply Chain Management in Pharmaceutical Industries. Review of Public Administration and Management, 3(1), 176-180.

Ferri, M., Ranucci, E., Romagnoli, P., \& Giaccone, V. (2017). Antimicrobial resistance: a global emerging threat to public health systems. Critical reviews in food science and nutrition, 57(13), 2857-2876.

Finch, P. (2004). Supply chain risk management. Supply Chain Management: An International Journal, 9(2), 183-196.

Ghorabaee, M. K, Amiri, M., Zavadskas, E. K., \& Antucheviciene, J. (2017). Supplier evaluation and selection in fuzzy environments: a review of MADM approaches. Economic research-Ekonomska istraživanja, 30(1), 1073-1118.

Govindan, K., Sarkis, J., Jabbour, C. J. C., Geng, Y., \& Trandafir, M. (2017). Eco-efficiency based green supply chain management: Current status and opportunities. European Journal of Operational Research, 10, 57.

Gupta, H., \& Barua, M. K. (2017). Supplier selection among SMEs on the basis of their green innovation ability using BWM and fuzzy TOPSIS. Journal of Cleaner Production, 152, 242-258.

Hsu, Y. L., Lee, C. H., \& Kreng, V. B. (2010). The application of Fuzzy Delphi Method and Fuzzy AHP in lubricant regenerative technology selection. Expert Systems with Applications, 37(1), 419-425.

Ishikawa, A., Amagasa, M., Shiga, T., Tomizawa, G., Tatsuta, R., \& Mieno, H. (1993). The max-min Delphi method and fuzzy Delphi method via fuzzy integration. Fuzzy sets and systems, 55(3), 241-253.

Jane Bower, D., \& Sulej, J. C. (2007). The Indian challenge: the evolution of a successful new global strategy in the pharmaceutical industry. Technology Analysis \& Strategic Management, 19(5), 611-624.

Jha, R. (2007). Options for Indian pharmaceutical industry in the changing environment. Economic and Political Weekly, 3958-3967.

Jiménez-González, C., \& Overcash, M. R. (2014). The evolution of life cycle assessment in pharmaceutical and chemical applications-a perspective. Green Chemistry, 16(7), 3392-3400.

Kale, D., \& Little, S. (2007). From imitation to innovation: The evolution of R\&D capabilities and learning processes in the Indian pharmaceutical industry. Technology Analysis \& Strategic Management, 19(5), 589-609.

Kelle, P., Woosley, J., \& Schneider, H. (2012). Pharmaceutical supply chain specifics and inventory solutions for a hospital case. Operations Research for Health Care, 1(2-3), 54-63

Kumar, A., \& Dash, M. K (2014). Factor exploration and multi-criteria assessment method (AHP) of multi-generational consumer in electronic commerce. International Journal of Business Excellence, 7(2), 213-236.

Kumar, A., Kaviani, M. A., Hafezalkotob, A., \& Zavadskas, E. K. (2017). Evaluating innovation capabilities of real estate firms: a combined fuzzy Delphi and DEMATEL approach. International Journal of Strategic Property Management, 21(4), 401-416.

Kumar, M., Basu, P., \& Avittathur, B. (2018). Pricing and sourcing strategies for competing retailers in supply chains under disruption risk. European Journal of Operational Research, 265(2), 533-543. 
Kumar, V., Holt, D., Ghobadian, A., \& Garza-Reyes, J. A. (2015). Developing green supply chain management taxonomy-based decision support system. International Journal of Production Research, 53(21), 6372-6389.

Kuo, Y. F., \& Chen, P. C. (2008). Constructing performance appraisal indicators for mobility of the service industries using Fuzzy Delphi Method. Expert Systems with Applications, 35(4), 1930-1939.

Lan, S., Zhang, H., Zhong, R. Y., \& Huang, G. Q. (2016). A customer satisfaction evaluation model for logistics services using fuzzy analytic hierarchy process. Industrial Management \& Data Systems, 116(5), 1024-1042.

Lintukangas, K., Kähkönen, A. K., \& Ritala, P. (2016). Supply risks as drivers of green supply management adoption. Journal of Cleaner Production, 112, 1901-1909.

Lücker, F., Seifert, R. W., \& Biçer, I. (2018). Roles of inventory and reserve capacity in mitigating supply chain disruption risk. International Journal of Production Research, 1-12 (In press).

Luthra, S., Kumar, V., Kumar, S., \& Haleem, A. (2011). Barriers to implement green supply chain management in automobile industry using interpretive structural modeling technique: An Indian perspective. Journal of Industrial Engineering and Management, 4(2), 231-257.

Luthra, S., Mangla, S. K., Chan, F. T., \& Venkatesh, V. G. (2018). Evaluating the Drivers to Information and Communication Technology for Effective Sustainability Initiatives in Supply Chains. International Journal of Information Technology \& Decision Making, 17(01), 311-338.

Ma, R. M., Yao, L. F., \& Huang, R. (2012). The green supply chain management risk analysis. In Advanced Materials Research (Vol. 573, pp. 734-739). Trans Tech Publications.

Mandal, S., \& Jha, R. R. (2018). Exploring the importance of collaborative assets to hospital-supplier integration in healthcare supply chains. International Journal of Production Research, 56(7), 26662683.

Mangla, S. K., Govindan, K., \& Luthra, S. (2017). Prioritizing the barriers to achieve sustainable consumption and production trends in supply chains using fuzzy Analytical Hierarchy Process. Journal of cleaner production, 151, 509-525.

Mangla, S., Madaan, J., \& Chan, F. T. (2013). Analysis of flexible decision strategies for sustainabilityfocused green product recovery system. International Journal of Production Research, 51(11), 34283442.

Mangla, S. K., Kumar, P., \& Barua, M. K. (2014). A flexible decision framework for building risk mitigation strategies in green supply chain using SAP-LAP and IRP approaches. Global Journal of Flexible Systems Management, 15(3), 203-218.

Mangla, S. K., Kumar, P., \& Barua, M. K. (2015a). Risk analysis in green supply chain using fuzzy AHP approach: A case study. Resources, Conservation and Recycling, 104, 375-390.

Mangla, S. K., Kumar, P., \& Barua, M. K. (2015b). Prioritizing the responses to manage risks in green supply chain: An Indian plastic manufacturer perspective. Sustainable Production and Consumption, 1 , $67-86$. 
Mangla, S. K., Kumar, P., \& Barua, M. K. (2016). An integrated methodology of FTA and fuzzy AHP for risk assessment in green supply chain. International Journal of Operational Research, 25(1), 77-99.

Mishra, N., Kumar, V., \& Chan, F. T. (2012). A multi-agent architecture for reverse logistics in a green supply chain. International Journal of Production Research, 50(9), 2396-2406.

Modgil, S., \& Sharma, S. (2017). Information Systems, Supply Chain Management and Operational Performance: Tri-linkage-An Exploratory Study on Pharmaceutical Industry of India. Global Business Review, 18(3), 652-677.

Mohanty, R. P., \& Prakash, A. (2014). Green supply chain management practices in India: an empirical study. Production Planning \& Control, 25(16), 1322-1337.

Moktadir, A., Rahman, T., Jabbour, C. J. C., Ali, S. M., \& Kabir, G. (2018). Prioritization of drivers of corporate social responsibility in the footwear industry in an emerging economy: A fuzzy AHP approach. Journal of Cleaner Production, 201, 369-381.

Moktadir, M. A., Ali, S. M., Mangla, S. K., Sharmy, T. A., Luthra, S., Mishra, N. and Garza-Reyes, J. A. (2018). Decision modeling of risks in pharmaceutical supply chains. Industrial Management \& Data Systems, 118(6) (in press).

Nazam, M., Xu, J., Tao, Z., Ahmad, J., \& Hashim, M. (2015). A fuzzy AHP-TOPSIS framework for the risk assessment of green supply chain implementation in the textile industry. International Journal of Supply and Operations Management, 2(1), 548-568.

Olson, D. L., \& Wu, D. (2011). Risk management models for supply chain: a scenario analysis of outsourcing to China. Supply Chain Management: An International Journal, 16(6), 401-408.

Patil, P. S., Kumbhoje, S. R., \& Patil, S. S. (2016). Pharmaceutical Waste Management-An Overview. Asian Journal of Pharmaceutical Research, 5(2), 1-8.

Prasad, S., Sundarraj, R. P., Tata, J., \& Altay, N. (2017). Action-research-based optimisation model for health care behaviour change in rural India. International Journal of Production Research, 1-19 (In press).

Qianlei, L. (2012, October). The study on the risk management of agricultural products green supply chain based on systematic analysis. In 2012 Second International Conference on Business Computing and Global Informatization (pp. 250-253). IEEE.

Rostamzadeh, R., Ghorabaee, M. K., Govindan, K., Esmaeili, A., \& Nobar, H. B. K. (2018). Evaluation of sustainable supply chain risk management using an integrated fuzzy TOPSIS-CRITIC approach. Journal of Cleaner Production, 175, 651-669.

Saaty, T. L. (1980). The analytic hierarchy process. New York: McGraw- Hill.

Saaty, T. L. (1980). The Analytical Hierarchy Process, Planning, Priority. Resource Allocation. RWS Publications, USA.

Samvedi, A., Jain, V., \& Chan, F. T. (2013). Quantifying risks in a supply chain through integration of fuzzy AHP and fuzzy TOPSIS. International Journal of Production Research, 51(8), 2433-2442.

Saranga, H., \& Phani, B. V. (2009). Determinants of operational efficiencies in the Indian pharmaceutical industry. International transactions in operational research, 16(1), 109-130. 
Seker, S., \& Zavadskas, E. K. (2017). Application of Fuzzy DEMATEL Method for Analyzing Occupational Risks on Construction Sites. Sustainability, 9(11), 2083.

Settanni, E., Harrington, T. S., \& Srai, J. S. (2017). Pharmaceutical supply chain models: A synthesis from a systems view of operations research. Operations Research Perspectives, 4, 74-95.

Shen, Y. C., Chang, S. H., Lin, G. T., \& Yu, H. C. (2010). A hybrid selection model for emerging technology. Technological Forecasting and Social Change, 77(1), 151-166.

Sreedevi, R., \& Saranga, H. (2017). Uncertainty and supply chain risk: The moderating role of supply chain flexibility in risk mitigation. International Journal of Production Economics, 193, 332-342.

Tahriri, F., Mousavi, M., Haghighi, S. H., \& Dawal, S. Z. M. (2014). The application of fuzzy Delphi and fuzzy inference system in supplier ranking and selection. Journal of Industrial Engineering International, 10(3), 2-16.

Tang, O., \& Musa, S. N. (2011). Identifying risk issues and research advancements in supply chain risk management. International journal of production economics, 133(1), 25-34.

Thakur, V., \& Ramesh, A. (2018). Analyzing composition and generation rates of biomedical waste in selected hospitals of Uttarakhand, India. Journal of Material Cycles and Waste Management, 20(2), 877-890.

Tseng, M. L., \& Chiu, A. S. (2013). Evaluating firm's green supply chain management in linguistic preferences. Journal of cleaner production, 40, 22-31.

Tyagi, S. (2016). An improved fuzzy-AHP (IFAHP) approach to compare SECI modes. International Journal of Production Research, 54(15), 4520-4536.

Van Laarhoven, P. J. M., \& Pedrycz, W. (1983). A fuzzy extension of Saaty's priority theory. Fuzzy sets and Systems, 11(1-3), 229-241.

Wang, X., Chan, H. K., Yee, R. W., \& Diaz-Rainey, I. (2012). A two-stage fuzzy-AHP model for risk assessment of implementing green initiatives in the fashion supply chain. International Journal of Production Economics, 135(2), 595-606.

Wee, S. Y., \& Aris, A. Z. (2017). Endocrine disrupting compounds in drinking water supply system and human health risk implication. Environment international, 106, 207-233.

Weraikat, D., Zanjani, M. K., \& Lehoux, N. (2016). Coordinating a green reverse supply chain in pharmaceutical sector by negotiation. Computers \& Industrial Engineering, 93, 67-77.

Wiengarten, F., Humphreys, P., Gimenez, C., \& McIvor, R. (2016). Risk, risk management practices, and the success of supply chain integration. International Journal of Production Economics, 171, 361-370.

Xie, Y., \& Breen, L. (2012). Greening community pharmaceutical supply chain in UK: a cross boundary approach. Supply Chain Management: An International Journal, 17(1), 40-53.

Yadav, G., Mangla, S. K., Luthra, S., \& Jakhar, S. (2018). Hybrid BWM-ELECTRE-based decision framework for effective offshore outsourcing adoption: a case study. International Journal of Production Research, 1-20 (in press) 
Yang, Z. K., \& Li, J. (2010, October). Assessment of green supply chain risk based on circular economy. In Industrial Engineering and Engineering Management (IE\&EM), 2010 IEEE 17Th International Conference on (pp. 1276-1280). IEEE.

Zadeh, L.A. (1965). Fuzzy sets. Information and Control, 8(3), 338-353.

Zavadskas, E. K., Turskis, Z., \& Tamošaitiene, J. (2010). Risk assessment of construction projects. Journal of civil engineering and management, 16(1), 33-46.

Zimmermann, H. J. (1996). Fuzzy control. In Fuzzy Set Theory-and Its Applications (pp. 203-240). Springer, Dordrecht.

\section{Appendix - A}

\section{Phase -1 Draft of Fuzzy Delphi Questionnaire}

Greetings!!!!

Dear respondent, we aim to analyze the risks in implementing Green Supply Chain in the pharmaceutical industry in the Indian context. We have identified 42 risks through literature. Please indicate their importance based on the following scale: $1=$ Very Low significance, $2=$ Low significance, 3 = Medium Low significance, $4=$ Medium significance, $5=$ Medium High significance, 6 = High significance, 7 = Very High significance

Please fill your response in prescribed column:

\begin{tabular}{|c|c|c|}
\hline S. No. & Name of Risk & Your Response \\
\hline 1. & Design Risk & \\
\hline 2. & Scarcity of Skilled Labour & \\
\hline 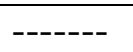 & ---------------------------------------------------------- & 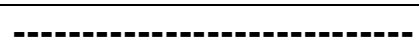 \\
\hline 42. & Inefficient inventory levels & \\
\hline
\end{tabular}

Next, please also provide your feedback on classifying the finalized risks in appropriate categories. 


\section{Phase -2 Fuzzy AHP Questionnaire for Risks}

Dear respondent, we aim to establish the relative importance of the above finalized risks. Suppose we take two risks, for example, operational and supply. If you think that operational risk is more important than supply risk in terms of implementing GSC in the pharmaceutical industry in India, then you can mark " 7 " which means "operational risk" is 7 times more important than "supply risk."

Please tick $(\sqrt{ })$ in appropriate box

\begin{tabular}{|c|c|c|c|c|c|c|c|c|c|c|}
\hline Goal & \multicolumn{9}{|c|}{ Importance } & Goal \\
\hline Main -risks & 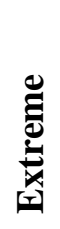 & 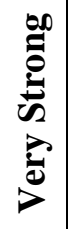 & 占 & 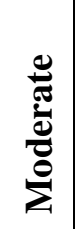 & 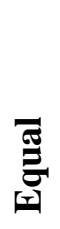 & 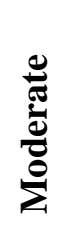 & $\stackrel{000}{\tilde{E}}$ & 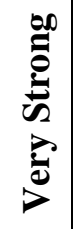 & 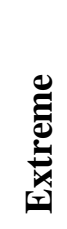 & Main - risk \\
\hline & 9 & 7 & 5 & 3 & 1 & 3 & 5 & 7 & 9 & \\
\hline Operational & & & & & & & & & & Supply \\
\hline Operational & & & & & & & & & & Product Recovery \\
\hline Operational & & & & & & & & & & Financial \\
\hline Operational & & & & & & & & & & Organization Governance \\
\hline Operational & & & & & & & & & & Environmental \\
\hline Operational & & & & & & & & & & Cold Supply Chain Technology \\
\hline- & & & & & & & & & & - \\
\hline Environmental & & & & & & & & & & Cold Supply Chain Technology \\
\hline
\end{tabular}

